University of Pennsylvania Carey Law School

Penn Law: Legal Scholarship Repository

Faculty Scholarship at Penn Law

2004

\title{
"A Question Which Convulses a Nation": The Early Republic's Greatest Debate About the Judicial Review Power
}

Theodore Ruger

University of Pennsylvania Carey Law School

Follow this and additional works at: https://scholarship.law.upenn.edu/faculty_scholarship

Part of the Constitutional Law Commons, Judges Commons, Law and Politics Commons, Legal History Commons, Legislation Commons, and the United States History Commons

\section{Repository Citation}

Ruger, Theodore, "'A Question Which Convulses a Nation": The Early Republic's Greatest Debate About the Judicial Review Power" (2004). Faculty Scholarship at Penn Law. 673.

https://scholarship.law.upenn.edu/faculty_scholarship/673

This Article is brought to you for free and open access by Penn Law: Legal Scholarship Repository. It has been accepted for inclusion in Faculty Scholarship at Penn Law by an authorized administrator of Penn Law: Legal Scholarship Repository. For more information, please contact PennlawIR@law.upenn.edu. 


\title{
"A QUESTION WHICH CONVULSES A NATION": ${ }^{\dagger}$ THE EARLY REPUBLIC'S GREATEST DEBATE ABOUT THE JUDICIAL REVIEW POWER
}

\author{
Theodore W. Ruger*
}

\begin{abstract}
What land is that where there are men, With noble blood in every vein, With heads most wise and noble mein, Whose hearts all fraud and guile condemn; Who charitably would explain The Constitution unto men, And spare the toil of thought to them? ${ }^{1}$
\end{abstract}

\section{INTRODUCTION}

In his important recent book on popular constitutional interpretation, Mark Tushnet poses a foundational question: "What would a world without judicial review look like?"2 For Tushnet and others who have asked it, answering the question generally requires resort to theory, comparative law, or both, because for over two centuries the American political regime has been one with at least some significant role for courts to play in determining constitutional meaning. ${ }^{3}$ This is particularly true when the constitutional question at issue is itself the nature and scope of the judicial review power. At least since Marbury v. Madison ${ }^{4}$ courts have taken an active part in asserting and defining their right to assess the constitutional validity of coordinate legislative

† Letter from Thomas Jefferson to George Thomson (June 22, 1825), in Thomas JefFerSON, CORRESPONDENCE 294, 295 (Worthington Chauncey Ford ed., I916) (addressing the Kentucky crisis over judicial review). Section III.A.2 of this Article discusses this letter in context, elaborating on Jefferson's and other national leaders' views on the Kentucky controversy.

* Associate Professor of Law, Washington University in St. Louis School of Law. Earlier versions of this Article were presented in faculty workshops at St. Louis University School of Law and Southern Illinois University Law School and benefited from commentary from participants in those sessions, as well as helpful insight from Stuart Banner, Rachel Barkow, David Barron, Eric Clayes, Barry Cushman, Brannon Denning, John Drobak, Joel Goldstein, Daniel Hulsebosch, Patrick Kelley, Larry Kramer, Maeva Marcus, Gerald Neumann, Scot Powe, Jennifer Prah Ruger, and Mark Tushnet. Michael Mano and Sarah Taylor provided excellent research assistance, and Kathie Molyneaux and others on the Washington University School of Law interlibrary loan staff were extremely helpful in obtaining the historical materials used in this project.

1 Poet's Corner, KY. GazeTte, June 2, 1826 (emphasis omitted) (spelling corrected). The punch line to this poetic query, and to those posed in several similar verses, is "Kentucky." Id.

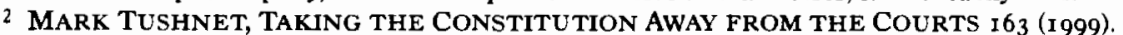

3 Tushnet's work is a case in point: after posing the question quoted above, he looks to Great Britain and the Netherlands as possible exemplars. See id. at I 63-64.

${ }^{4} 5$ U.S. (I Cranch) 137 (1803). 
enactments. Even in recent scholarly accounts that stress the role of nonjudicial actors in shaping a consensus on judicial review early in American history, and even when judges are subject to electoral controls, courts are always part of the story. ${ }^{5}$

This Article explores an unusual episode in the American constitutional experience: a period of intense popular discourse in earlynineteenth-century Kentucky when the polity considered, briefly actualized, and ultimately rejected a regime of unabashed legislative supremacy without any meaningful judicial review. Following a state supreme court decision that struck down a popular debtor relief statute, the state legislature dissolved the court and replaced it with a successor institution whose review authority was tightly limited. This action was justified on the theory that authority to interpret the constitution was "never with the judges" and "always with the people" or their legislative agents. ${ }^{6}$ With judicial authority thus eviscerated and the legislature solidly opposed to such authority, supporters of judicial review pursued the "only privilege" left open to them in their efforts to reestablish the doctrine: "to complain and remonstrate, by appealing to the people." The legislature's decision situated the question of judicial authority squarely, and solely, in the realm of popular electoral politics, where it dominated the state's political discourse for three successive annual election cycles. ${ }^{8}$ Although sporadic objections to judicial review have been commonplace in the nation's political history, the intensity, concrete focus, and broad public character of the Kentucky debate are unique, and the surviving rhetoric reveals much about fractured early American conceptions of the proper scope of judicial authority and the proper locus and methodology of constitutional interpretation.

What does this episode tell us about attitudes toward judicial review in early-nineteenth-century America? This question is difficult to

\footnotetext{
5 See infra section III.C.I, pp. 888-92, for a discussion of this new scholarship. See also Barry Friedman, The History of the Countermajoritarian Difficulty, Part One: The Road to Judicial Supremacy, 73 N.Y.U. L. REV. 333 (I998) (exploring the role of nonjudicial actors in shaping views on judicial review in early American history); Larry D. Kramer, The Supreme Court, 2000 Term-Forezoord: We the Court, I I HARV. L. REV. 4 (200I) (same). Kramer expands and refines his treatment of these issues in LARRY D. KRAMER, THE PEOPLE THEMSELVES: POPULAR CONSTITUTIONALISM AND JUDICIAL REVIEW (forthcoming 2004).

6 LIBERTY SAVED, OR THE WARNINGS OF AN OLD KENTUCKIAN, TO His FEllow Citizens, on the Danger of Electing Partisans of the Old Court of Appeals, AT THE NeXt August Election, TO Represent THEM IN THE NEXT General AsSEMBLY OF KENTUCKY I 8 (Louisville, Ky., Wm. Tanner I 825 ) [hereinafter LibERTY SAVED].

7 George Robertson et al., Protest of the Minority, Against the ACt ReORGAN[I]ZING THE COURT OF APPEALS (1824) [hereinafter PROTEST OF THE MINORITY], reprinted in GEORGE ROBERTSON, SCRAP BOOK ON LAW AND POLITICS, MEN AND TIMES 92, 94 (Lexington, Ky., A.W. Elder I855).

8 See infra section I.B, pp. 844-55.
} 
answer from the occasionally conflicting campaign literature that proliferated on both sides of the debate and from the inconsistent election results. Precisely what fascinates about the Kentucky crisis is the extent and intensity of this disagreement on the basic question of judicial authority in constitutional matters. Although a solid majority of Kentucky voters ultimately endorsed judicial review, a large minority apparently persisted in rejecting such authority. ${ }^{9}$ This bitter disagreement is even more telling in light of several recent studies asserting a settled consensus in favor of judicial review (albeit in a more modest form than the modern doctrine) among early-nineteenth-century Americans. ${ }^{10}$ On one hand, the Kentucky crisis demonstrates that significant pockets of opposition to judicial review persisted even two decades after Marbury, thirty-five years after the Framing, and a halfcentury after independence. On the other, the episode was eventually resolved when the public - despite early Kentucky's ultramajoritarian political culture - voted to reestablish judicial review, and this fact can be read to support claims of an emerging popular acceptance of the doctrine.

What is less ambiguous, and what supports the broader conclusions of other scholars regarding the origins and acceptance of judicial review, ${ }^{11}$ is that the kind of judicial review Kentuckians voted to reestablish was significantly more modest than the current doctrine, leaving some meaningful interpretive authority with the public and the elected branches of government. Even an important supporter of judicial review in the Kentucky debate acknowledged that "[t]here may be constitutional questions which can be decided only by the public; and their only mode of deciding them is at the polls." 12 This moderation was good politics at the time, and it helps explain why the public was willing to reestablish judicial review. Other, more specific historical lessons also emerge from a careful analysis of the Kentucky dispute. For one, the Marbury precedent was relatively unimportant in this context, even in a pitched battle over its major proposition. Moreover, the episode attracted illuminating commentary from various national leaders - Marshall, Madison, and Jefferson - none of whom supported the side of popular constitutional supremacy. Additionally,

\footnotetext{
9 See infra section I.B.3, pp. 852-55.

10 See, e.g., ROBERT LOWRY Clin'ton, MaRbURY V. Madison AND JUdicial RevieW 102-O3 (I989); WILLIAM E. NELSON, MARBURY V. MADISON: THE ORIGINS AND LEGACY OF JUDICIAL REVIEW 75-77 (2000); Kramer, supra note 5, at 87-88. The accounts given in these works, along with the new insight that the Kentucky episode provides, are discussed below in section III.C, pp. 889-97.

11 See Kramer, supra note 5, at 33-1 Io (discussing judicial review in the context of "popular constitutionalism").

12 PLeBIAN, TO THE GOVERNOR ELECT OF KENTUCKy - No. VII, reprinted in ROBERTSON, supra note 7 , at I22, 124 .
} 
upon further exploration, one can see how the crisis and some of its major actors influenced the development and articulation of Andrew Jackson's constitutional program.

Even beyond these historical and historiographical insights, the Kentucky controversy is an interesting case study because of its unique fusion of specific subject matter (judicial review) with specific means of resolution (public discourse and electoral politics). This was an exceedingly rare event in American history: a debate over the proper nature of dualist democracy played out in a political space that was, for a time, purely monistic. ${ }^{13}$ It was a "world without judicial review,"14 where the public was asked directly to decide whether it preferred such a world. The public's choice to reinstate judicial review was, in one obvious sense, a victory for the doctrine and its supporters, but the dynamic that produced this result was a robust exercise of popular higher lawmaking. The public considered the constitutional question of judicial review with all of the depth, breadth, and focus that Bruce Ackerman's higher lawmaking paradigm requires, ${ }^{15}$ and it gave its answer in two statewide votes with a clarity that more complicated national election results rarely display. Herein lies an intriguing paradox of the Kentucky episode: it can be regarded both as a limited endorsement of judicial review and as a successful exercise of meaningful popular constitutional interpretation. In this sense, it is a conceptual inversion of the conventional Marbury story: judicial review established, but from the bottom up rather than from the top down - a "social process ... 'done' at a given time and by a given act," but by the masses rather than by "the Great Chief Justice."16

To provide a context for discussion, this Article initially explores the chronology and theoretical contours of the Kentucky judicial review controversy. Given the asserted uniqueness of the episode, however, two related threshold questions require brief answers. The first of these is addressed in detail in section I.A: why did so much dissent erupt in Kentucky at a time when, according to much current scholarship, Americans had generally accepted a limited judicial review power? ${ }^{17}$ Certain features of the Kentucky political and cultural regime were not unique to that state, but several specific triggers were.

\footnotetext{
13 These terms are borrowed from Bruce Ackerman's work on American "dualist democracy." See i BRUCE ACKERMAN, We THE PEOPLE: Foundations 3-33 (I 99I).

14 TUSHNET, supra note 2 , at $\mathrm{I} 63$.

15 See I ACKERMAN, supra note 13 , at 266-80 (describing the framework for assessing when public higher lawmaking has taken place).

16 Alexander M. Bickel, The Least Dangerous Branch: The Supreme Court AT THE BAR OF POLITICS I (1962) (famously describing the Marbury opinion).

17 Although their accounts differ in important respects, many scholars who have explored the history of judicial review agree on two general propositions: First, the judicial review power practiced by Marshall and his contemporaries was significantly narrower, in various ways, than that
} 
A second question asks the opposite: why did similar episodes of sustained opposition to the basic power of horizontal judicial review ${ }^{18}$ not occur elsewhere in early-nineteenth-century America, either on a national or state level? The answer helps to explain recent scholarship's emphasis on the emerging public acceptance of judicial review during the same years when the issue fractured the Kentucky polity. In an era of national politics when even ardent political critics of the Marshall Court typically invoked a vision of "departmentalism" - a theory of constitutional interpretation in which all three branches, including the judiciary, had some interpretive role ${ }^{19}$ - no national figures argued for an outright elimination of the judicial review power. The absence of national debate on this fundamental point may be independently probative of a broader consensus about the legitimacy of judicial review, and some scholars have construed it as such. ${ }^{20}$

However, five features of national politics in the early nineteenth century may have created the appearance of more unanimity on judicial review than actually existed, thus masking underlying public skepticism of the kind that surfaced in 1820 s Kentucky. First, the Marshall Court's reluctance to find acts of Congress unconstitutional meant that the Supreme Court's authority to review coordinate legislative enactments was almost never a concrete subject of debate in the first half of the nineteenth century. ${ }^{21}$ Second, vigorous disagreement on other con-

practiced by the modern Supreme Court. Second, Americans in the early nineteenth century generally accepted this modest version of judicial review. See infra section III.C.I, pp. 888-92, for a discussion of this scholarly consensus.

18 Throughout this Article, "horizontal judicial review" refers to a court's refusal to apply a statute enacted by a coordinate legislature because the court regards the statute as incompatible with a relevant constitutional constraint. The adjective "horizontal" is used to distinguish this basic power from the "vertical" review authority exercised by the United States Supreme Court over state legislative enactments. As described in the following pages, the latter was much more controversial than the former in the early nineteenth century.

19 For a discussion of departmentalism in early American constitutional thought, see, for example, Michael Stokes Paulsen, The Most Dangerous Branch: Executive Power To Say What the Law Is, 83 GEO. L. J. 2 I 7, 228-40, 245-50 (I994).

20 See ClintoN, supra note ID, at IO8 (describing the "general acquiescence in Marbury's version of judicial power"); Michael J. Klarman, How Great Were the "Great" Marshall Court Decisions?, 87 VA. L. REV. I I I I, I I 7 (2001) (explaining that by the time Marbury was decided, "the power of judicial review was sufficiently well settled that even Marshall's critics had no gript with him for exercising it").

21 From Marbury until Dred Scott v. Sanford, 60 U.S. (I 9 How.) 393 (I857), the Suprem Court declared no federal statute unconstitutional. See R. KENT NEWMYER, THE SuPREMr COURT UNDER MARSHALl AND TANEY 3I (1968). Much of the criticism of Marbury, the on case in which the Marshall Court did hold a federal law unconstitutional, was directed not at thi Court's claim of a right to review congressional statutes, but rather at its allegedly politically mo tivated encroachment on executive authority. See infra p. 88I. In his comprehensive study o reactions to the case, Robert Clinton finds only four rather minor statements in which contempo raries criticized Marshall's exercise of horizontal review authority. See ClinTON, supra note ic at $107-08$. 
stitutional questions, most notably those relating to vertical issues of federalism, predominated in national political discourse, thus diminishing opportunities for a focused debate over coordinate judicial review. ${ }^{22}$ Third, just as the federalism debate obscured a squarely presented discussion of judicial review, so too did the sharp partisan divisions among national politicians. These partisan fault lines meant that much early criticism of the Court was cast in political - or even personal - terms, rather than invoking more abstract objections to judicial authority. ${ }^{23}$ Fourth, as Barry Friedman has explained, the federal system of the new United States did more than generate contentious debate about the vertical allocation of national and state authority that might have crowded out discourse about horizontal judicial review. It also created a structural hierarchy that ameliorated the practical impact of many of the Marshall Court's opinions, thereby generally muting popular criticism of the Court and its authority. ${ }^{24}$ Because the Court's decisions had to be implemented by state judges and state and federal executive officials, these intervening actors could moderate, or overtly flout, the Supreme Court's mandates, dampening their practical effect. As shown below, one controversial assertion of judicial review by a state high court, without any such intermediate sovereignty between the court's unpopular opinion and the public, provoked a more vigorous popular response. Finally, the personal backgrounds of the actors in the national political arena might have fostered a consensus on judicial review that not all Americans shared. Most national politicians of the time were lawyers, and most - by constitutional design - were from elite economic and professional cir-

\footnotetext{
22 American politicians in the early nineteenth century were preoccupied with vertical questions of how authority was to be allocated between the federal government and the states under the new constitution. See, e.g., Daniel A. Farber, Judicial Reviere and Its Altematives: An American Tale, 38 WAKE FOREST L. REV. 415, 424-32 (2003). The Marshall Court's assertion of authority to review state high court judgments and to invalidate state legislation caused more controversy than its asserted authority to review federal laws, and it produced more voluminous criticism. When it reviewed federal statutes, the Marshall Court almost always affirmed their constitutionality, a pattern that often intensified criticism of the Court by advocates for state authority. The only criticism of the Court's horizontal review power with regard to such affirmations was that the Court should have been more assertive in reviewing acts of Congress. See Clinton, supra note IO, at 108.

23 See Friedman, supra note 5, at 358 ("Politics in the late 1700 s and early 1800 s were partisan to a degree difficult to appreciate fully today...."). The Marshall Court operated in a highly divided national polity, and contemporaries regarded the Court as a political institution that occasionally took sides in the contentious debates of the time. Given the Marshall Court's association with the Federalist Party, it is difficult to interpret any Republican criticism of the Court as a critique of the judicial review power in an abstract sense. See $i d$.

24 See id. at 393-97 (describing states' defiance of the Supreme Court a resistance that rendered the Court's power largely ineffectual).
} 
cles. ${ }^{25}$ Records from the Kentucky schism reveal that people with such professional backgrounds tended to support judicial review more than other voters. Thus, although critical of particular Marshall Court actions, national politicians regardless of party may have been more likely than average Americans to accept horizontal judicial review as an abstract principle.

Given all of these confounding factors on the national political scene, we might look to state-level debates in the decades following Marbury to examine American objections to judicial review more thoroughly. But here, too, there is a paucity of explicit political debate on the question. Judge Gibson's famous dissent in the Pennsylvania case of Eakin $v$. Raub ${ }^{26}$ notably repudiated the basic review power, but at the time that opinion generated little discussion outside the courts. $^{27}$ In his general survey of the practice of judicial review in the states during this period, William Nelson attributes the lack of overt debate to the fact that "by 1820 the doctrine of judicial review had attained general acceptance" in the states. ${ }^{28}$ Nelson notes, however, that the type of review that state courts practiced at the time was narrower than modern judicial review. ${ }^{29}$ State court exercises of judicial review typically touched on jurisdictional matters, and in Nelson's account, state courts were successful in "leaving to legislatures the resolution of social conflicts," rather than themselves deciding highly contested issues of constitutional law and public policy. ${ }^{30}$

But judicial intrusion into a divisive area did occur in Kentucky in 1823, when the state's highest court struck down a debtor relief law in the midst of a crippling economic depression. ${ }^{31}$ The decision ignited early-nineteenth-century America's most sustained, intense, and theoretically extreme debate over the legitimacy of judicial review. Nowhere else in this time period was the basic question of the courts' constitutional review authority so squarely presented for political debate uncluttered by partisan divisions or claims about the vertical scope of national judicial authority. Nowhere was the argumentative space so neatly framed by electoral politics - in this instance, by three

25 On the rationale for this constitutional design, see GORDON S. WOOD, THE CREATION OF THE AMERICAN REPUBLIC I 776-I 787 , at 506-I8 ( 1969 ) (noting that "through the artificial contrivance of the Constitution overlying an expanded society, the Federalists meant to restore and to prolong [a] kind of elitist influence in politics" at the national level).

26 I2 Serg. \& Rawle 330, 344 (Pa. 1825) (Gibson, J., dissenting).

27 Gibson's opinion became widely discussed only decades after he wrote it. See CLINTON, supra note 10 , at 138

28 William E. Nelson, Changing Conceptions of Judicial Review. The Evolution of Constitutional Theory in the States, $1790-1860$, I 20 U. PA. L. REV. I I66, I I69 (I972).

29 See id. at I I $70-72$.

30 Id. at 1173

31 See Lapsley v. Brashears, I4 Ky. (4 Litt.) 4r (1823); Blair v. Williams, I4 Ky. (4 Litt.) 33 (1823). 
successive annual elections in which the only meaningful issue before the voters was the question of judicial authority to construe the constitution. This convergence of factors produced a uniquely rich body of written source material: a bevy of published legislative resolutions, pamphlets, and periodicals directed at a broad-based, and relatively literate, state electorate. Despite a longstanding academic "obsession" 32 with the countermajoritarian aspects of judicial review in American history, few constitutional lawyers or historians have explored this particular episode in detail. ${ }^{33}$ Doing so informs a broader understanding of the gradual acceptance of judicial review in the American constitutional tradition.

This Article proceeds in three parts. Part I describes the political and legal background that gave rise to Kentucky's judicial review crisis and details the chronology of judicial decision, legislative response, and political discourse that framed, and ultimately resolved, the controversy. Part II focuses on the rhetorical and ideological contours of the debate, with reference to broader theories of constitutionalism prominent in American history and articulated by current scholarship. Part III discusses the Kentucky debate's impact beyond its particular place and time, and it explores the lessons that the episode provides for broader historical and theoretical accounts of judicial review in American history.

32 Steven L. Winter, Indeterminacy and Incommensurability in Constitutional Law, 78 CAL. L. REV. I441, I52 I (1990).

33 A few older histories treat the narrative of this episode in some detail and are helpful in framing the contextual description in Part I. See 2 WILliam ELSEY CONNELLEy \& E.M. COUlTER, History OF KENTUCKY (Charles Kerr ed., I922); ARNDT M. STICKLES, The Critical Court Struggle IN Kentucky I819-1829 (1929); B.J. Benthurum, Old and Neve Court Controversy, 6 KY. L.J. 173 (1918); Philip Lindsley, The Old and the New Court: A Kentucky Judicial Episode, I6 GREEN BAG 520 (I904). For a careful historical discussion of the broader debtor relief controversy that also explores the court crisis, see Sandra Frances VanBurkleo, "That Our Pure Republican Principles Might Not Wither": Kentucky's Relief Crisis and the Pursuit of "Moral Justice," I8 18-1826 (1988) (unpublished Ph.D. dissertation, University of Minnesota). Several constitutional law scholars have mentioned this controversy briefly in a few pages or in footnotes as part of larger works, but without detailed analysis of the rhetorical dimensions of the disagreement or their implications for broader historical and theoretical debates. See, e.g., DWight WILEy Jessup, ReaCtion AND ACCOMMOdation: THE UNited STATES SUPREME COURT AND POLITICAL CONFLICT I 809-1835, at 228-29 (I987) (describing the controversy in less than two pages); FORREST MCDONALD, STATES' RIGHTS AND THE UNION: IMPERIUM IN IMPERIO, $1776-1876$, at 83-84 (2000) (briefly outlining the factual history of the controversy); I CHARLES WARREN, THE SUPREME COURT IN UNITED STATES HISTORY 637-43 (rev. ed. 1937) (describing the Kentucky controversy as part of a relatively brief discussion of Kentucky's criticisms of the Court); Friedman, supra note 5, at 407-09 (describing the Kentucky episode as "one of the oddest chapters in American judicial history"). This Article draws on additional primary sources and explores the episode from the perspective of constitutional theory and history in a way that these other works do not. 


\section{CONTEXT AND CHRONOLOGY}

In May I825, the aged Marquis de Lafayette passed through Kentucky as part of an honorific tour of the United States. ${ }^{34}$ His visit provided a brief respite from the bitter struggle over judicial authority that otherwise preoccupied the state. The embattled legislature had urged the governor to arrange the war hero's visit and, despite a limited state budget, had authorized the expenditure of "any sum which shall be necessary" to invite and receive him..$^{35}$ In anticipation of his visit, the legislature commissioned a large portrait of Lafayette to be painted "as a memento ... of the devotion of the good people of this State, to the principles which his distinguished services contributed to establish." 36

Had Lafayette paid attention to the state's political discourse at the time of his visit, he would have noticed profound disagreement about what exactly those "principles" were. Juxtaposed against the widely shared secular hagiography of Lafayette (as well as of Washington and Jefferson $)^{37}$ was a bitter political contest over the proper structure of republican government, in which each side accused the other of betraying the revolutionary generation's legacy. Half a century after independence, Kentuckians disagreed profoundly about what kind of democracy should prevail in the American republic. The touchstone for this debate was the question of judicial review.

What was it about this particular place, and this particular time, that produced such an intense and sustained reaction to a particular exercise of judicial review? The reasons are three. First, the Kentucky political regime was robustly majoritarian in ways that some other states were not. ${ }^{38}$ But it was incompletely majoritarian: it retained a life-tenured judiciary at a time when many similar states appointed judges for fixed terms, and it exhibited a pattern of land ownership that concentrated property rights in the hands of a relative few.

Second, the state high court's invalidation of an important mortgage relief statute was not merely unpopular, but unpopular with re-

34 See I LEWIS COLLINS, HISTORY OF KENTUCKY 32 (I924).

35 Resolutions Requesting the Governor To Invite General La Fayette To Visit the State of Kentucky, 1824-I825 Ky. Acts 2 I 5, 2 I 7 [hereinafter Lafayette Invitation Resolutions].

36 Preamble and Resolution for Procuring a Portrait of General La Fayette, I824-I825 Ky. Acts 279,280 .

37 The same resolution that praised Lafayette on the occasion of his visit to the United States also invoked Washington. See Lafayette Invitation Resolutions, supra note 35, at 2 I6. Jefferson's name was invoked by both sides in the court struggle. See, e.g., LAFAyetTe, To THE PEOPLE $7,10,36,43$ (I825) (pseudonymous new-court pamphlet); PlEBIAN, supra note I2, at I 26 (pseudonymous new-court pamphlet).

38 This factor, and the others that follow, generally track Barry Friedman's "countermajoritarian frame" of factors that might influence a polity's reaction to an exercise of judicial review. See Friedman, supra note 5 , at $347-54$. 
spect to a subject of utmost importance to Kentucky citizens at a time of constant land litigation, heavily mortgaged farmers, and deep economic recession. Once the political crisis over judicial review erupted, the alleged indeterminacy of constitutional rules became an express subject for debate. The critics of judicial review maintained that the court's ruling represented nothing more than the judges' will. From the perspective of these opponents of judicial review, the court's formal jurisprudence was not only politically motivated, but purposely obfuscatory - an illegitimate resort to "metaphysics and law books" 39 rather than common public understandings of the constitution.

Finally, with respect to a remedial statute enacted specifically to temper the severity of judicial execution proceedings, the court's opinion was final, and it was authoritative enough to provoke an intense popular response.

\section{A. The Political Culture and Legal Landscape of Early-Nineteenth-Century Kentucky}

Early-nineteenth-century Kentucky exhibited a dramatic inconsistency between the state's political regime and its pattern of land ownership. The state's political culture was egalitarian and transparent, but its pattern of land ownership was inegalitarian and uncertain. The tension between these two structures presaged an interbranch conflict over land policy as legislative majorities passed laws that favored tenants, small farmers, and debtors, while the judicial system often protected the putative property interests of creditors and landlords. This latent fault line was exacerbated by a severe economic recession that strained debtors and creditors alike, creating simultaneously more strident demands for legislative relief and more assertive legal claims for enforcement of property and contractual rights. ${ }^{40}$

I. "Steady to the principles of pure republicanism." 41 - Few states were as broadly majoritarian ${ }^{42}$ in political structure or culture as those

39 Patrick Henry, The Bank Dinner, an Expose of the Court Party of KenTUCKY, AND THE CURTAIN DRAWN FROM THE HOLY ALLIANCE OF AMERICA 48 (Frankfort, Ky., Amos Kendall \& Co. I824) [hereinafter BANK DINNER] (pseudonymous pamphlet).

40 For a general overview of the nationwide upheaval associated with this particularly severe depression, see Samuel Rezneck, The Depression of $1819-1822$, A Social History, 39 AM. HIST. REV. 28 (1933).

41 Ethelbert Dudley Warfield, The Kentucky Resolutions of i798: AN HISTORICAL STUDY 75 (New York, G.P. Putnam's Sons I887) ("Kentucky, remote from the contaminating influence of European politics, is steady to the principles of pure republicanism, and will ever be the asylum of her persecuted votaries." (quoting Governor James Garrard's speech to the Kentucky legislature on November 7,1798 ) (internal quotation mark omitted)).

42 I use the term "majoritarian" here and throughout this Article because it is more precise, and less freighted with interpretive baggage, than the term "democratic." Similarly, to call Kentucky politics of this period "republican" is of little descriptive help; in the vocabulary of early- 
formed on the western frontier in the twenty years following ratification of the national constitution. As one scholar has noted, "[c]onfidence in a powerful legislature, checked by frequent election, seems to have been the cardinal principle with the makers" of the constitutions of these newer states. ${ }^{43}$ In Kentucky, the most salient structural manifestation of this majoritarian emphasis was the practice of annual statewide legislative elections in which all freemen, regardless of property ownership, could vote. ${ }^{44}$

These annual exercises of popular sovereignty contributed to a political culture that gave primacy to popular discourse on, and public resolution of, contested questions. The frequent election cycles meant that political campaigns were always ongoing; the corresponding rhetoric and debate spread statewide through a large number of periodicals and pamphlets that circulated generally or in response to specific issues. ${ }^{45}$ During the Kentucky judicial review struggle, more than twenty-five papers circulated in the state, and Kentuckians published numerous other pamphlets and tracts relating to judicial review. ${ }^{46}$

This emphasis on popular authority was not limited to matters of "public policy" as distinguished from "constitutional law." Indeed, most voters in early-nineteenth-century Kentucky would not have un-

nineteenth-century politics, both sides to any debate in Kentucky sought that mantle, including judicial review's supporters and opponents alike. See infra Part II.

43 William T. Utter, Judicial Review in Early Ohio, I4 MISs. VAlley HIST. Rev. 3, 3 (1927) (footnote omitted) (referring to Ohio's constitution of 1802 ). This statement is a similarly apt description of Kentucky's constitution.

44 This majoritarian emphasis was also manifested in the operation of the state governments once they were constituted. For instance, a simple majority of the Kentucky legislature could override the governor's veto. See RoBERT M. IRELAND, THE KENTUCKY STATE CONSTITUTION 5 (1999).

45 Like its revolutionary and Framing-era predecessors, this generation was a politically literate one, and the state put an unusual emphasis on universal public education. The governor in I 816 declared that "[k]nowledge and virtue are every where the surest basis of public happiness; the strongest barrier against oppression; a powerful check to mal-administration, by rendering it necessary for those in power to secure not the blind, but the enlightened confidence of the people." Governor Gabriel Slaughter, Speech to the Kentucky Legislature (Dec. 3, 1816), in KY. GAZETTE, Dec. 9, 1816. Accordingly, he maintained that "[e]very child born in the state should be considered a child of the republic, and educated at the public expence, where the parents are unable to do it." Id.

This democratization of education was notable to outsiders. An anonymous Virginian visiting the state at the height of the judicial review crisis in 1825 commented that the number and affordability of schools in Kentucky were "unequalled any where else" and "put[] within the reach of both sexes of all classes the opportunity of acquiring" knowledge. LETTERS ON THE CONDITION OF KENTUCKY IN 1825 , at 39 (Earl Gregg Swem ed., 1916) [hereinafter LETTERS]. He further opined that "the population of Kentucky are the most intelligent, and are the best informed in all matters connected with the politics of the state, of any whom I have met with in any other country." $I d$.

46 See STICKLES, supra note 33 , at $96-100$. The content of these publications is described and quoted throughout Part II. 
derstood that distinction, much less accepted it. ${ }^{47}$ Throughout Kentucky's early history, issues of constitutional construction occasionally surfaced and were resolved in popular election campaigns. A notable precursor to the public judicial review debates was an I8I 7 constitutional controversy over gubernatorial succession. ${ }^{48}$ Following the death of the incumbent governor, the lieutenant governor succeeded him in office. Critics of the validity of the succession, after losing in the legislature, took their constitutional case to the public in the months preceding the legislative elections, calling for a legislature that would implement the proper mechanism for gubernatorial replacement: a new election. ${ }^{49}$ This campaign, like the judicial review debate that was to follow, was replete with competing constitutional arguments made to the "people of Kentucky," who were urged to "[t]hink for yourselves, and act like men who deserve to be free ... coolly, deliberately, and wisely." 50

This open and transparent political regime, which tended to resolve controversies in the arena of electoral politics, was instrumental to both the onset of the judicial review crisis and its resolution. ${ }^{51}$ With regard to the former, an understanding of the background political culture helps explain the unusual intensity of Kentuckians' reaction to an unpopular exercise of judicial review. In a political regime dedicated to popular resolution of disputed issues, the countermajoritarian nature of judicial review was not merely a conceptual "difficulty," but instead a basic affront to the prevailing understanding about the locus of sovereignty in society. ${ }^{52}$ With regard to the latter, the state's majoritarian regime also dictated the terms of resolution of the debate by

\footnotetext{
47 Judicial review opponents would attempt to draw a distinction between constitutionalism and ordinary legal construction (vesting the former in the public and the latter in the judiciary). This distinction fits well with Larry Kramer's recent work about early American constitutionalism, see Kramer, supra note 5, and is analyzed in greater length later in this Article, see infra Part II

48 See 2 CONNELLEY \& COUlTER, supra note 33 , at 582-9r.

49 See id. at 586-88.

50 A Kentuckian, To the PeOple of Kentucky, reprinted in ROBERTSON, supra note 7 , at 5 , ig (pseudonymous pamphlet). In the view of two early-twentieth-century historians, this exercise in popular constitutionalism fueled "old heresies that the will of the majority is supreme and transcendent," an effect that contributed to the judicial review crisis of the following decade. 2 CONNElLEY \& CoUlTER, supra note 33 , at 59 r.

51 The structure of Kentucky's political regime may have had a transformative effect on people's beliefs about popular sovereignty and participation. Alternatively, the causation may have been the reverse: constitutional structure might have followed from popular attitudes at the time of the state's founding. Either way, the relationship was evident to outsiders. A Virginian visiting at the time of the judicial review crisis wrote that "[t]he unrestrained freedom of election guaranteed by the constitution . . . awakes within [the voters] a spirit of inquiry," by virtue of which all of Kentucky's citizens were "taught to feel their influence in society, and an equality with the most respectable citizens of the state." LETTERS, supra note 45, at 39-40.

52 Part II examines these theoretical questions in detail.
} 
channeling the foundational question of the judiciary's authority into the arena of electoral politics. The supporters of strong judicial review needed the voting public to ratify their constitutional vision, so they put to the electorate the question whether they could withdraw certain constitutional subjects from exclusive popular control.

But Kentucky's constitutional regime was not completely majoritarian, inscfar as it retained appointed, life-tenured judges. This fact is important to understanding the intensity of the popular response to the exercise of judicial review. Other states that prioritized majority rule had already gone further than had Kentucky, making their judiciaries subject to popular influence by instituting fixed terms of office; many would soon implement elected judiciaries. ${ }^{53}$ When unpopular decisions issued from courts in these states, the reactions were less institutionally cataclysmic because the focus was on replacing specific judges rather than on repudiating the abstract principle of judicial review. Ohio's history illustrates this point. In I807, a state supreme court decision invalidating a state law on the jurisdiction of justices of the peace touched off an initial flurry of rhetorical opposition very similar to the later episode in Kentucky. ${ }^{54}$ Ohio judges served only for seven-year terms, however, and after immediate impeachment efforts narrowly failed to garner the requisite supermajority, the legislature simply waited until it could appoint more desirable judges. The fixed terms of office thus obviated the need for a direct institutional assault on the courts. 55

2. "The laws of Virginia for the appropriation of lands were the greatest curse that ever befell Kentucky." 56 - Kentucky's widespread suffrage democratized political participation, and its annual elections prioritized frequency and transparency in the resolution of disputed issues. In contrast, land ownership in Kentucky was highly concentrated in large - and often absentee - landholders, and the state's famously inaccurate and obscure land title system bred incessant, lengthy, and expensive litigation. Moreover, the one-sided compact through which Kentucky had attained its separation from Virginia contained a provision that protected Virginia landlords by disabling

53 For instance, Ohio judges were appointed for fixed seven-year terms, as were supreme court justices in New Jersey. Vermont judges served for only one-year terms. For general information about early judicial selection and tenure in the states, see American Judicature Society, Judicial Selection in the States, at http://www.ajs.org/js (last visited Dec. 6, 2003).

54 See Utter, supra note 43 , at $9-$ - 9 . The legislative articles of impeachment brought against one of the Ohio judges in 1808 charged - as a ground for removal - that he "at divers times did adjudicate and determine, that the court had full power to set aside, suspend and declare null and void, any act or acts of the legislature." Id. at I4-I5 (quoting the articles of impeachment) (internal quotation marks omitted).

55 See id, at 19,22

$56{ }_{2}$ COLLINS, supra note 34 , at 633 . 
the new state's sovereign authority in the critical area of land policy. The juxtaposition of all of these factors with an assertively majoritarian political regime meant that courts often became the arbiters of conflicts between newly enacted positive law and claims of vested property rights. It was one of these conflicts that precipitated the judicial review crisis this Article describes.

From the beginning of the eighteenth century, Kentucky was surveyed early and often by speculators and settlers moving west. ${ }^{57}$ Their settlement predated national independence, so land grants in Kentucky were not systematically regulated under the national land office system that governed the distribution of most lands north of the Ohio River. ${ }^{58}$ Instead, land was settled and claimed under the laws of Virginia, a system that "was notorious for its wasteful inefficiency." 59 The Virginia government - and later the government of Kentucky itself made public land grants liberally in return for military service or application of large companies. ${ }^{60}$ Despite the large number of original grants, land ownership became concentrated: twenty-one large speculators laid claim to one-quarter of Kentucky's land. ${ }^{61}$ Humphrey Marshall, the Chief Justice's cousin, owned over four hundred thousand acres. ${ }^{62}$

Land in Kentucky was also poorly surveyed and recorded. Most of the state was settled before it was surveyed, and the post hoc surveying that took place often was performed by amateurs and was egregiously erroneous. ${ }^{63}$ Virginia (and later Kentucky) was careless with the boundaries of land grants in Kentucky, and the result was that the state was "shingled over" 64 with land claims that over-

\footnotetext{
57 An excellent treatment of this process and other aspects of early Kentucky history is found

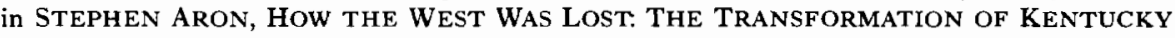
FROM DANIEL BOONE TO HENRY CLAY 58-89 (1996).

58 See Paul W. Gates, Tenants of the Log Cabin, 49 Miss. VAlley Hist. Rev. 3, 3-5 (I962).

59 Id. at 3 .

60 Mary K. Bonsteel Tachad, Federal Courts in the Early Republic: KenTUCKY I 789-I816, at I7० (I978). Virginia and Kentucky eventually issued a total of 143,228 different land grants. $I d$. at 170 n. Io.

61 See Gates, supra note 58 , at 6 n.9.

62 See id. at 6 . From early on, Kentuckians worried about the corrosive effect such large landholdings might have on their democracy. At the first Kentucky constitutional convention, the delegates resolved that parcels of land larger than those that the owner could personally cultivate were "subversive of the fundamental principles of a free republican Government" and would produce "innumerable evils." Id. at 9 (quoting Journal of the First Kentucky Convention, Dec. 27, 1784-Jan. 5, 1785 (Thomas P. Abernethy ed.), I J. S. HIST. 76 (1935)) (internal quotation marks omitted).

${ }^{63}$ See id. at $4-5$.

64 Henry Clay stated that the "same identical tract was frequently shingled over by a dozen claims." Id. (quoting COMMENTATOR (Frankfort), Mar. 6, 1822) (internal quotation marks omitted).
} 
lapped. ${ }^{65}$ In 1797 , Kentucky's surveyor general reported to the legislature that existing grants totaled approximately twice the state's actual acreage. ${ }^{.60}$

All of this produced extensive litigation. ${ }^{67}$ Mary Tachau, in her meticulous study of the Kentucky federal courts of the time, observes that "[e]verything connected with land policy and land laws, and their administration, seems in retrospect to have provided grounds for litigation." 68 Lower federal courts, generally sensitive to their important mediating role in the area of land policy, adopted devices to make legal outcomes more consistent with local norms. For instance, the judge of the federal district court in Kentucky frequently empaneled advisory juries, even while sitting in equity. ${ }^{69}$ But despite the moderated substantive jurisprudence, land litigation was still expensive and timeconsuming - win or lose. Tachau concludes that, as to Kentucky land rights, "[w]hat is certain is that it must have been difficult for anyone to maintain his right to land without a considerable investment in lawyers' fees and in legal processes." 70 Faced with such expense and hassle, many small farmers simply left the state for pastures that were, if not greener, at least more regularly surveyed. At a time when other, more secure land was readily available to settlers willing to move north into Indiana and Illinois or west into Missouri, it was not worth the trouble to stay and hire lawyers to defend even a relatively strong land claim in Kentucky. ${ }^{71}$

For those who chose to remain in the state, Kentucky's excessive land litigation had different consequences, two of which are germane to the judicial review controversy. First, many Kentuckians developed

65 See TACHAU, supra note 60 , at I 70 \& n.Io. In the face of such uncertainty, landowners resorted to innovative means of strengthening their titles, often at ancillary benefit to the public fisc: one county had twice its actual acreage listed on its tax rolls because residents were eager to fortify their property rights by obtaining generous tax titles. See LEWIS N. DEMBITZ, KENTUCKY JURISPRUDENCE I 85 ( 1890 ).

66 ARON, supra note 57 , at 84

67 Prescient early Kentuckians foresaw this result. In the 17805 , Reverend David Rice wrote "The spirit of speculation was flowing in such a torrent that . . I looked forward to fifty or sixty years ... and saw the inhabitants engaged in very expensive and demoralizing litigations abou 1 their landed property." Id. at 8 I (quoting David Rice) (internal quotation marks omitted). .

68 TACHAU, supra note 60 , at 175 .

69 See id. at $179-82$; see also ARON, supra note 57 , at 96-99.

70 TACHAU, supra note 60 , at 175.

71 This pattern of emigration included a small event that would ultimately have vast signifi. cance for American political and constitutional history. Frustrated with the constant litigatior over his small tract of land in Hardin County, Thomas Lincoln sold his Kentucky plot in $18 \mathrm{It}$ and moved to Indiana (and later Illinois). With him went his seven-year-old son Abraham, whc thus propitiously grew up and entered politics in a free-soil state. See I ALBERT J. BEVERIDGE ABRAHAM LINCOLN I 809-1858, at 34-37 (I 928). As was often the case with the excessive litiga tion in Kentucky, this was not Thomas Lincoln's first experience with a title suit: he had beer ousted from a prior Kentucky landholding in another lawsuit a few years earlier. See id. at $24^{-25}$ 
a distaste for the lawyers and judges who seemed to be among the few in the state to profit, materially and professionally, from the recurring title disputes. Such resentment was not new in Kentucky politics, ${ }^{72}$ nor was it unique to that state in the early nineteenth century. ${ }^{73}$ It gained even greater force in times of economic recession, such as the one that crippled the state beginning in $18 \mathrm{rg}$. Said one tract of that era: "Lawyers, clerks, sheriffs, constables made great crops," but "most of those of the people were diminished."74 In this period of depressed agricultural markets, mortgage foreclosure actions proliferated, and creditors, often from out of state, used the court system to execute on property securing bad loans. ${ }^{75}$ Consequently, Kentuckians came to resent not only lawyers, but also the courts themselves. The opposition to judicial review that erupted in the 1820 s reflected this animus, and one thrust of the popular constitutionalists' argument was a desire to remove constitutional interpretation from the corrupt legalist domain of attorneys and judges.

The second public response to the ongoing land litigation was a popular effort to reform the substantive common law and statutory regime that governed the two staples of the court system: real property title disputes and mortgage foreclosures. Through popular new enactments, the state legislature sought to ameliorate the harsh results that often confronted defendants in ejectment and foreclosure actions. If such majoritarian positivism altered property rights and tweaked the existing socioeconomic order, so much the better as far as its proponents were concerned. In I82 I, when Kentucky became the first state in the United States to abolish imprisonment for debtors - a reform that many creditors thought impaired their contractual rights - a leading paper in the state heralded the "real triumph over the deep rooted aristocratic principles that have continued to obstruct the progress of republican doctrine in this, as well as most of the states of the union." 76

Two other state laws aimed at protecting defendants in real estate eviction and foreclosure actions were also of this (mildly) redistributive

\footnotetext{
72 Stephen Aron describes the anti-lawyer sentiment that many Kentuckians held even before statehood was attained. See ARON, supra note 57, at 85-89. At Kentucky's second constitutional convention in 1799 , one-third of the delegates had voted to bar lawyers from serving in the state legislature. JoAn Wells Coward, Kentucky in the NEW Republic: The Process of CONSTITUTION MAKING I54 (I979).

73 See, e.g., RICHARd E. Ellis, The Jeffersonian CRISIS: COURTS AND POLITICS IN THE YOUNG REPUBLIC II I-22 (I97 I).

742 CONNELLEY \& COULTER, supra note 33 , at 607 (quoting an 1824 pamphlet) (internal quotation marks omitted).

75 See Rezneck, supra note 40 , at $45-47$ (1933).

76 CONNELley \& COUlTER, supra note 33, at 6I4-I5 (quoting KY. GAZETTE, Dec. 5, 182 I). A year earlier, the Kentucky state legislature had abolished debt imprisonment for women and had come close to doing so for men, declaring that the entire county was their "jail." Id.
} 
cast and, when juxtaposed with the rigidity of early-nineteenth-century Contract Clause doctrine, were bound for constitutional trouble in the courts. The first of these was a set of "occupying claimant" statutes that gave important rights to tenants and squatters in ejectment actions. Reflecting a Lockean conception of the virtues of cultivation and improvement (and a corresponding disparagement of the rights of absentee landowners), these laws provided that a squatter could, upon eviction, recoup from the plaintiff landowner the value of any improvements. Since the value of these improvements was determined by local juries, these awards were often quite generous. ${ }^{77}$ Such laws were particularly important in Kentucky, given the clouds on almost every landowner's title; not only intentional squatters but also those who built homes and farms fully believing they owned the land upon which they lived were at risk of eviction.

As a general matter, occupying claimant laws were not rare in early America, nor were they thought to be constitutionally infirm or even particularly contrnversial. Elsewhere in the country, there would probably have been no constitutional problem with a legislature's revising its occupying claimant laws to make them more tenant-friendly, as Kentucky's legislature did on several occasions between 1797 and $1820 .{ }^{78}$ But the Kentucky legislature was under a unique constitutional disability in this area, arising from the stringent terms of its I79I compact with Virginia. ${ }^{79}$ To protect its landowners, many of whom held large estates in Kentucky, Virginia required as a conditior of Kentucky's secession that all private land rights in the new stat "remain valid and secure" and be determined in accordance with thi then-existing laws of Virginia. ${ }^{80}$ In 1819 , a landholder invoked thi: compact, and the federal constitution's Contract Clause, in a challeng, to Kentucky's revised occupying claimant laws.

The saga of the contentious litigation and interstate negotiatiol that followed is independently interesting, but for present purposes th last act will suffice: in Green $v$. Biddle, the U.S. Supreme Court invali dated Kentucky's occupying claimant laws as contrary to the feder: constitution. ${ }^{81}$ The decision, originally authored by Justice Story br then reissued by Justice Washington after reargument, treated the stat compact as a contract and therefore reasoned that Kentucky's laws ra afoul of the Contract Clause. ${ }^{82}$ The opinion is an odd one, and it he

\footnotetext{
77 See Gates, supra note 58, at I I-I 2.

78 See id. at $\mathrm{II}_{1}{ }_{4}$ (listing changes to Kentucky's occupying claimant laws).

79 See I WARREN, supra note 33 , at 637 .

80 Id. (quoting the 1791 compact) (internal quotation marks omitted)

812 I U.S. (8 Wheat.) I, $92-93(1823)$.

82 Id.
} 
attracted much criticism from scholars of the Court's history. ${ }^{83}$ It was also roundly pilloried in the Kentucky press and in the state legislature at the time of its issuance. But even though the state's papers and legislators let fly with a predictable bevy of vitriolic criticism against the Supreme Court, ${ }^{84}$ Kentucky could not alone convince Congress to evince any particular outrage over the Court's decision..$^{85}$

Kentuckians felt doubly wronged in the Green case: the inflexible superintendence of the Marshall Court might have been expected, but the position of Virginia, Kentucky's onetime ally in support of strong state sovereignty, was especially disappointing. ${ }^{86}$ The Green $v$. Biddle episode operated together with concurrent economic turbulence to significantly diminish Kentuckians' sense of autonomy in their political affairs. The former stripped the legislature of a key component of its remedial positivism, just when the latter was producing increasing cries for relief, and there seemed little Kentucky could do about either. Accordingly, when the state's own high court similarly interfered with a popular statute limiting foreclosures, this pent-up frustration would be visited on that institution, which was at least arguably within legislative control.

\section{B. The Crisis Unfolds}

Like the occupying claimant laws, the statute that provoked the Kentucky crisis over judicial review altered the preexisting law gov-

83 See, e.g., EdWard S. CORWin, John Marshall and the CONSTITUTiON i 88 (19 I9) (describing the Green decision as "pedantic" and "unworkable"); G. EDWARD WHITE, HISTORY OF THE SUPREME COURT OF THE UNITED STATES: THE MARSHALl COURT AND CULTURAL CHANGE, I 8 I5-1835, at 646 (1988) ("On the surface, Green $v$. Biddle seems a curious, almost reckless decision."); BeNJAMIN Fletcher Wright, JR., The CONTRACt ClaUse of THE CONSTITUTION 47, 214 (1938) (arguing that the Green case was perhaps the Marshall Court's "most far-fetched ... extension of the contract clause," born "out of an excess of zeal for broadening [its] scope").

84 See, e.g., Preamble and Resolutions of the Legislature of Kentucky in Relation to the Late Decision of the Court of Appeals on the Replevin and Endorsement Laws, and of the Supreme Court of the United States on the Occupying Claimant Laws of Said State, I823-18 4 Ky. Acts 488, 5 I 6 [hereinafter Resolutions on Court Decisions] ("solemnly protest[ing], in the name and on behalf of the good people of Kentucky, against the erroneous, injurious, and degrading doctrines of the opinion of the Supreme Court of the United States . . . in the case of Green and Biddle").

85 For a discussion of the specific reforms offered in Congress by Senator Richard Johnson and others, see I WARREN, supra note 33 , at $644-5 \mathrm{I}$.

86 Many of the absentee landholders affected by the occupying claimant laws were Virginians, and despite repeated appeals by Henry Clay and others, Virginia chose to support the legal challenge and, ultimately, the Supreme Court's ruling in Green. Clay recognized the irony of Virginia's newfound support for the Court's rulings. See Letter from Henry Clay to Francis Brooke (Aug. 28, 1823), in 4 THE WORKS OF HENRY CLAY 78, 80 (Calvin Colton ed., New York, A.S. Barnes \& Co. I855) ("When, in the case of Cohans and Virginia, her authority was alone concerned, she made the most strenuous efforts against the exercise of power by the Supreme Court. But when the thunders of that Court were directed against poor Kentucky, in vain did she invoke Virginian aid."). 
erning land disputes. This new statute - the Relief Act of I820 governed actions for foreclosure and ejectment. ${ }^{87}$ Kentucky farmers were heavily mortgaged in the early nineteenth century, ${ }^{88}$ and the severe economic depression of 1819 to 1822 , coupled with the state's related shortage of hard specie (the only currency many lenders would accept), produced a high default rate. By I821, a third of the state had been conveyed to banks or nonresidents through forced sales, foreclosures, or other forms of judicial process. ${ }^{89}$ The legislature responded with a politically popular "relief law" that gave creditors in foreclosure a choice: either accept payment in Bank of Kentucky notes, or undergo a two-year stay of execution. ${ }^{90}$ The diminished value of Bank of Kentucky notes meant that the statutory choice was illusory: at least for any hard-money creditor, ${ }^{91}$ the statute was tantamount to an automatic two-year stay. Creditor litigants soon raised the critical question whether this stay law, when retroactively applied to loans executed before I82 I, "impaired" the loan contracts in violation of the Kentucky and U.S. Constitutions.

I. The Triggering Decision. - Advocates for the relief law invoked two primary arguments in support of its constitutionality. The first was a categorical distinction between substance and procedure: a state may not impair the substantive law governing contractual relations, the argument went, but it may alter the legal process for enforcing contracts. ${ }^{92}$ This argument had some support in Sturges $v$. Crowninshield, ${ }^{93}$ in which Chief Justice Marshall stated that "[t]he distinction between the obligation of a contract, and the remedy given by the legislature to enforce that obligation,.... exists in the nature of things. Without impairing the obligation of the contract, the remedy may certainly be modified as the wisdom of the nation shall direct." 94 The replevin law's supporters seized upon this reasoning and its "clear distinction" between contractual obligation and remedy. ${ }^{95}$

87 See STICKLES, supra note 33 , at 22-23.

88 See id. at I6-I 8.

89 See Gates, supra note 58 , at 8

90 See STICKLES, supra note 33 , at $22-23$.

91 Bank of Kentucky notes at this time had declined in value over twenty percent relative to Bank of United States currency, and twenty-eight percent relative to specie. See Mathias, supra note I I 7 , at I64 n.28

92 See Petition for Rehearing Filed by George M. Bibb, Blair v. Williams, I4 Ky. (4 Litt.) 34 (1823), and Lapsley v. Brashears, I4 Ky. (4 Litt.) 46 (I823) [hereinafter Bibb Petition], reprinted in I 4 Ky. (4 Litt.) 87, I I5-I6 (I823).

93 I 7 U.S. (4 Wheat.) I 22 (1 819 ).

94 Id. at 200 .

95 SPEeCh OF SAMUel Daveiss, ESQ. 5 (Frankfort, Ky., Amos Kendall \& Co. n.d.) (speech delivered before the Kentucky House of Representatives on December 5, I823). Legal historians may recognize a certain irony in the polarity of this argument about the categorical separation of right and remedy. Much scholarship has described the arid formalism of early-nineteenth-century 
In the paired cases of Blair $v$. Williams ${ }^{96}$ and Lapsley $v$. Brashears, ${ }^{97}$ the Kentucky Court of Appeals, the state's highest court, rejected this categorical distinction. Separated from the enforcement scheme, the court reasoned, a contract is a mere "obligation of conscience." 98 A state's enforcement mechanism is integral to meaningful contract law: "The remedy . . . afforded by civil institutions, is the instrument with which the aggregate force of society is wielded, and by which men are obliged to perform their duties towards each other ...."99 If the remedy was part of the contractual obligation, did the two-year replevin law "impair" that obligation under the state and federal constitutions? The court held that it did, reasoning that the constitutional text precluded "weaken[ing]" the remedy as well as destroying it. ${ }^{100}$

Beyond this disagreement over the nature of contracts, the parties (and the court) also differed about the appropriate function of the judiciary in reviewing legislation, presaging the broader judicial review debate that was to follow. Rather than flatly denying the judiciary's power to review legislation, as other state leaders would later demand at the peak of the judicial review controversy, the attorney defending the replevin law before the court of appeals adopted a more nuanced approach, similar to a modern appeal for deference to the political branches. Arguing for rehearing, he asked the court to consider the practical calamities that would arise from the rulings' "abridgment of the powers of legislation" and their "restrictions upon the power of the people to consult their happiness, and provide, by the accustomed and ordinary acts of legislation, for [life's] exigencies."101 In asking the court to defer to the legislature's judgment, the petition linked its defense of state legislative autonomy to the reliable rhetorical tropes of Jeffersonian republicanism, arguing that "the loss of the internal powers of the state governments[] will substantially convert the federal[] into a consolidated government" and that "liberty will not long survive . . such consolidation." ${ }^{102}$

\footnotetext{
jurisprudence, and in cases involving Contract Clause claims, that formalism was usually invoked to defend private property rights against state regulation. See, e.g., MORTON J. HORWITZ, THE TRANSFORMATION OF AMERICAN LAW, I780-1860, at 255 (I977). Here, however, it was the supporters of the state remedial law who made the categorical claim that a clear distinction between (protected) contractual rights and (mutable) enforcement mechanisms "exists in the nature of things." Sturges, 17 U.S. (4 Wheat.) at 200.

96 I4 Ky. (4 Litt.) 34 (1823).

97 I4 Ky. (4 Litt.) 46 (1823).

98 Blair, 14 Ky. (4 Litt.) at 36.

99 Id. at 37.

100 Lapsley, 14 Ky. (4 Litt.) at 47.

101 Bibb Petition, supra note 92, at 88.

102 ld. at 88-89.
} 
The court of appeals rejected the petition for rehearing, thus reaffirming its original decision. There, it had offered a different vision, one of constitutional and judicial supremacy over the legislature. The court discussed the operation of governments "possessing no written constitution," where "the power of the legislature knows no limit short of its will,"103 and tersely concluded that "such is not the nature of this government." 104 On the contrary, said the court, the federal and state constitutions set limits that are "paramount to the acts of the legislature," 105 and thus "any act of the legislature transcending those limits[] shall be void."106 The court then declared its own supremacy in determining whether an act indeed transcended constitutional limits. Although the legislature that passed the replevin law "must be supposed to have entertained the opinion" that it was constitutional, "it is not in the opinion of the legislature that the court is to search for the true meaning of the constitution."107 Instead, "it is incumbent on the court to pronounce the paramount authority of the constitutions," and to "decide for itself upon the constitution" based on "its own reflections and deliberations."108 Pausing to note the "deep sense of ... duty" produced by "its station" in the constitutional order, the court of appeals gave a nod to the "high respect" in which it held the legislature ${ }^{109}$ but then declared the replevin law void. ${ }^{10}$

Reaction to Lapsley and Blair was swift and severely critical. Kentucky's governor summarized their effect on the state's majoritarian polity: "The legislature and the country were startled at this decision." 111 The court had "wrested from the representatives of the people the power to suspend the operation of the laws in any case of contract" during war, famine, and depression, and thus prioritized the "the rigid enforcement of contracts . . . [over] justice to the absent debtor or the safety of the republic."112 Soon after the court's ruling, the state legislature drafted lengthy resolutions protesting the opinion. ${ }^{113}$ The resolutions criticized not only the court's reasoning, but also its author. ity to void these laws for unconstitutionality. They thus opened a dialogue about judicial power that would dominate the state's politica

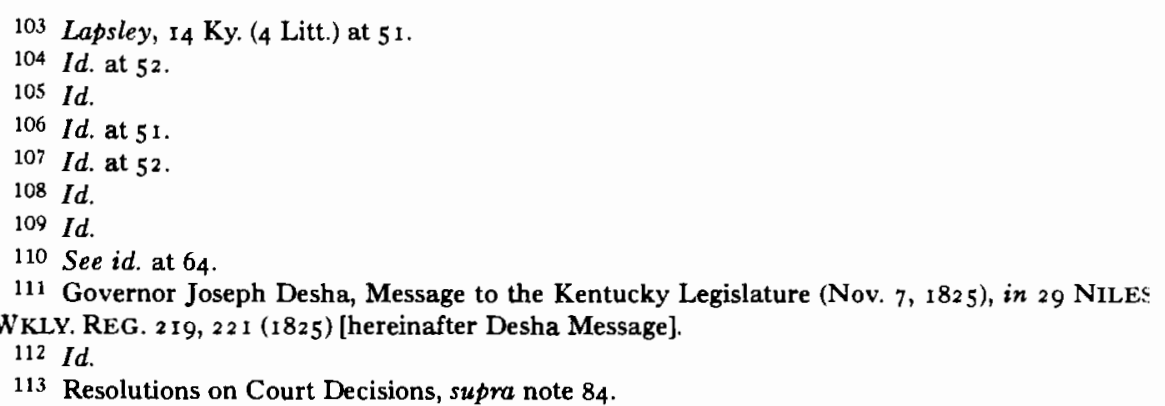


discourse for the next three years."14 "[W]hether [the replevin laws] were or were not expedient," said the resolutions, they "are believed to be constitutional and valid," and should, if undesirable, "be repealed by the Legislature, and not by the Appellate Court."115

The preamble to one of the resolutions also reflected the legislature's wounded defensiveness about its own sovereignty that had been created by the close proximity of the state court's ruling and the Supreme Court's Green v. Biddle decision:

[T] The Appellate Court of the nation and state, (by consentaneous impulse,) ... uttered their respective edicts. The former proclaimed that the state of Kentucky possessed no legislative dominion over its soil; the latter, that the Legislature of the state possessed no power to alter, amend or modify its remedial laws. The former having disfranchized [sic] the state, and reduced it to the degrading posture of a province of Virginia - the latter denies to it even provincial legislative powers. ${ }^{116}$

The appellate judges of "the nation" were insulated from the state legislature by geography and constitutional design, but the judges of the state's highest court enjoyed no such luxury. Legislative attacks on the court and the institution of judicial review commenced immediately, and this opposition and the response launched by the judges and their supporters would dominate political activity in the state for the next three years.

The controversy played out in three distinct phases. First, opponents of judicial review power sought to remove the offending judges through means specified in the state constitution's text. Second, when these efforts failed to gain the requisite supermajority support, judicial review opponents temporarily achieved legislative supremacy by disbanding the court of appeals and establishing a new state high court, packed with judges who disavowed any power to review laws for their constitutionality. But the original judges refused to go quietly into constitutional exile, and in the third phase of the crisis they and their supporters consciously turned the elections of I825 and I826 into referenda on the question of judicial review. The old-court judges ultimately achieved reinstatement. During this three-year progression, both sides framed the legitimacy of judicial review as the primary issue

\footnotetext{
114 The debate actually began eighteen months before in the wake of the county circuit court's invalidation of the replevin laws, but it gained full prominence after the court of appeals ruling. In response to the county circuit judge's ruling, in May 1822 the legislature declared that the judge had "grossly transcended his judicial authority" and appointed a committee to report on the matter. 2 CONNELlEY \& COUlTER, supra note 33 , at 630 (quoting 23 NILES' W KLY. REG., Supp. I55 ( 1822$)$ ). The report denied that "the judicial department has a power, beyond control, to defeat the general policy of the state, deliberately adopted by the representatives of the people." Id.

115 Resolutions on Court Decisions, supra note 84, at 5 I5

116 Id.
} 
in the state's legislative debates, the popular press, and electioneering materials, yielding an unusually rich record of popular argument on both sides of the question. Part II examines the rhetorical and ideological dimensions of these two positions in depth, but the next few pages summarize the three chronological phases of the dispute.

2. Removal and Reorganization. - Despite vehement public reaction to Lapsley and Blair, the legislative majority that opposed the court had limited options in their immediate aftermath. The incumbent governor supported the court's ruling, and both of the constitution's stated methods for removing judges required an unattainable two-thirds supermajority. These were only temporary obstacles, for the election upcoming in August I824 provided an immediate opportunity to strengthen the majority in favor of removing the judges. The governor's office, the entire House of Representatives, and one-quarter of the Senate seats were contested in that election, and critics of the court's exercise of judicial review made that the central issue in the campaign.

This first round of electoral politics went to the opponents of judicial review. In August 1824, they won the governorship and significant majorities in the state House and Senate. The gubernatorial candidate championed by opponents of the court's decision, Joseph Desha, carried fifty-nine of the state's seventy-six counties and won sixty-three percent of the popular vote. ${ }^{117}$ Opponents of judicial review trumpeted these results as confirmation of the public desire to curtail judicial power. Placecards at a celebratory banquet for the new governor soon after the election bore the inscription: "The Constitution of Kentucky: Its interpretation is known to the people of this Commonwealth, and is not to be found in the breasts of three judicial tyrants." 118

If such invective caused the state's three high court judges to have qualms about their job security, they did not have to wait long before realizing their fears. Immediately upon convening in the fall of 1824 , the legislature set about finding a way to remove the offending judges and replace them with other jurists who had a properly diminished conception of the judicial role. The most direct path to this end was a provision in the Kentucky Constitution that provided for removal of judges by the governor after two-thirds "address" of both houses, "for any reasonable cause, which shall not be sufficient ground of impeachment." 119 Once the new governor initiated the articles of ad-

\footnotetext{
117 See STICKLES, supra note 33, at 43; Frank F. Mathias, The Relief and Court Struggle: Halfway House to Populism, 7 I REG. KY. HIST: SOC. I54, I69 (1973).

118 STICKLES, supra note 33, at 43; see also Public Dinner, Ky. GAZETTE, Aug. 26, I824 (toasting the judiciary, "[a] separate coordinate .. . but not a Supreme department of our Government").

119 KY. Const. of I799, art. IV, $\$ 3$.
} 
dress, the legislative debate centered on the question whether a judge could be addressed out of office merely for being wrong, albeit in good faith, in his interpretation of judicial authority. Opponents of the court argued, based on the interpretive principle of ascribing independent meaning to each part of the constitutional text, that the inclusion of address in addition to impeachment was intended for just that circumstance. The legislature asserted that it had the authority to remove judges "for any mere error of judicial opinion, . . . notwithstanding that error shall have been committed in the course of judicial decision, if it shall inflict upon the community such injury as in their belief shall amount to a reasonable cause for his removal from office." 120 This assertion came in response to the judges' statement that some malfeasance beyond good-faith error was required for removal. ${ }^{121}$ Put to a vote in December I824, the proposal to remove the judges by address received a substantial majority in each house but fell short of the requisite two-thirds approval. ${ }^{122}$

A year earlier, an effort to convene a constitutional convention and amend the document to create an elected judiciary had failed to gain the requisite Senate majority, in part because of fears of reopening the question of emancipation, which had been prominent when the constitution was amended two-and-a-half decades before. ${ }^{123}$ These setbacks forced the legislative majority to be more creative and aggressive in its efforts to curtail the review authority of the judges. As then-Governor Desha later put it, to "rid the country of these erroneous and dangerous principles, the majority now deemed it necessary to resort to [its] constitutional power of abolishing the court and establishing another, composed of other men, and restricted in its power over the constitutionality of legislative acts." ${ }^{124}$ To achieve this end, on Christmas Eve

120 Preamble and Resolution Vindicating the Constitutionality of Replevin Laws, and the Right of the Legislature To Remove Judges for Error of Opinion, in Reply to the Response of the Judges of the Court of Appeals, I824-I825 Ky. Acts 242, 278 [hereinafter Replevin Laws Resolution].

121 See JOHN BOYLE ET AL., THE RESPONSE OF THE JUDGES OF THE COURT OF Appeals, to the Preamble, Resolutions and address, Proposed by a JoInt COMmittee of the Senate and House of Representatives, for the Purpose of REMOVING THEM FROM OFFICE 13 (1824) [hereinafter RESPONSE OF THE JUDGES] ("[I] it should be conceded, that we erred in these decisions, by a mistake of the head, and not of the heart, still it would furnish no ground for Legislative interposition, or authorize our removal ....").

122 The motion passed the House 6I-39 and the Senate 23-I2. See 2 CoNNELley \& CoulTER, supra note 33 , at 630 .

123 See id. at 628 . To amend constitutional text, Kentucky's second constitution (ratified in I 799 and in force until 1849 ) required first, that a majority of each legislative house approve a convention call, and second, that a majority of voters approve the call in two successive annual statewide elections. See Robert M. IRELAND, THE KENTUCKy STATE CONSTITUTION: A REFERENCE GUIDE 5 (I999). On emancipation arguments leading up to the 1799 convention, see COWARD, supra note 72 , at I I 8-23.

124 Desha Message, supra note I I I, at $22 \mathrm{I}$. 
of I824, majorities of both houses passed a judicial reorganization bill that was subtle neither in intent nor in operation: it provided for immediate dissolution of the existing court of appeals and creation of a new "Supreme Court . . . styled the Court of Appeals."125 The Act limited the new court's authority to void or decline to apply legislative acts to cases in which all four of the court's judges were in agreement. ${ }^{126}$ Despite that statutory concession permitting judicial review in at least some (unanimous) cases, as explained below the new-court party's public rhetoric was more absolute, denying that judges could legitimately exercise any review of legislative enactments. ${ }^{127}$

As a constitutional device, the reorganization proposal lacked both the textual grounding of removal by address and the obvious legitimacy of a constitutional convention. But those failings were outweighed (in the short term, at least) by the fact that judicial reorganization could be implemented via an ordinary statute, thus avoiding the supermajority requirements that had undone other options. The Reorganization Act passed the Senate quickly, and in a tumultuous latenight session described by an observer as resembling "a camp nightmeeting, in confusion and clamor," 128 the House passed the measure by a vote of 54-43. Governor Desha - already on the floor as a lobbyist that night - promptly signed the bill, and within a few weeks he had filled the four seats on the new court with political allies. ${ }^{129}$

The Act's dubious constitutionality was evident at the time of its passage and was the subject of immediate debate. Proponents of the Act argued that although the state constitution provided for a court of appeals, it gave the legislature control over the specific establishment of such an institution. Therefore, the legislature could disband and reestablish the high court. The court of appeals, supporters of the Act argued, was "not for the private benefit of the hired judges"; when the court housing the judges was dissolved, so too were the judges' seats. ${ }^{130}$ Law courts were no different from public grist mills, and if "[y]ou build another mill ... that does not oblige you to employ in it

\footnotetext{
125 An Act To Repeal the Law Organizing the Court of Appeals, and To Re-Organize a Court of Appeals, 1824-1825 Ky. Acts 44, 44 (I824).

126 See id. at 48 .

127 See infra section II.B.I, pp. 870 74.

128 Plebian, TO THE GOVERNOR EleCt OF KeNTUCKy - No. VIII, reprinted in RoBERTSON, supra note 7, at I27, I 27; see also John C. Doolan, The Old Court-New Court Controversy, I I GREEN BAG 177, I82 (1899) (describing how the "wildest excitement" ensued when the bill was introduced).

129 See STICKLES, supra note 33 , at 58,60 .

130 LIBERTY SAVED, supra note 6 , at 26.
} 
the miller of the former one; it may be, that the management of the new establishment is over his capacity." 131

The very content of the Reorganization Act insulated it from constitutional scrutiny - at least such scrutiny as might previously have come from the judicial branch. This immunity from judicial oversight was evident at the time, and the altered balance of power provoked sharp critique and dire prognostication. If the Act was enforced, proclaimed the legislative minority, "liberty is in danger, justice is in danger, morality is in danger, religion is in danger, and every thing dear and sacred is in danger. We will have no living constitution, and against bad times and bad men there will be no security."132 George Roberston, a leading supporter of the old court in the legislature and in the subsequent popular debate, described the Act as a "fatal blow that is aimed at the very heart of the constitution."133 Robertson and his allies were initially disconsolate once they realized that the Reorganization Act would become law; he lamented on the House floor that "the die is cast - the constitution falls!"134

3. Response and Retrenchment. - Such fatalistic resignation by iudicial review's supporters was not long-lasting. Soon after the Reoryanization Act's passage, three important decisions took place that would shape the content and direction of the subsequent public desate. First, proponents of a robust judicial authority, having failed in he legislative debates, chose to make questions of judicial and legislaive power public issues in the election of August 1825. Old-court ;upporters accused the legislative majority of "destroying the indesendence and purity and impartiality of the judiciary," and supporters If the judiciary had "only [one] privilege" left open to them: "to comslain and remonstrate, by appealing to the people."135 They continued hese popular appeals for two election cycles, through 1826 , and the inti-judiciary side responded in kind. This reciprocal populism reulted in two successive referenda on the judicial review question and roduced a rich dialogue analyzed in the next Part. ${ }^{136}$

Also helping to frame the popular debate was the legislative majorty's own decision to repeal the underlying relief and replevin laws that he court of appeals had struck down. It is unclear what motivated his decision. It may have reflected dissatisfaction with the policy out-

131 Id. The same document that invoked the miller analogy also turned to a martial one: "As in me of war, when your enemy is shut up in a fort, from which he annoys you, and you cannot atter him nor induce him to come out, you blow up his fort...." Id. at $\mathrm{r}$.

132 PROTEST OF THE MiNORITy, supra note 7 , at 93.

133 STICKLES, supra note 33, at 57 (quoting George Robertson, Speech on the Bill To Re'rganize the Court of Appeals (Dec. 23, 1824 ), in ROBERTSON, supra note 7, at 76,90 )

134 Id. (quoting Robertson, supra note $\mathrm{I} 33$, at 90 ).

135 PROTEST OF THE MINORITY, supra note $\bar{i}$, at 93-94.

136 See infra Part II 
comes of the laws, an improving economic and monetary situation, or, most interestingly, a strategic decision by the legislature to demonstrate its own capacity for constitutional construction, thereby enhancing its claim of interpretive supremacy. Whatever the intent, the repeal of the underlying relief legislation helped to focus the subsequent public debate on more general questions of judicial review. This sharpening of debate has been noted by historians, one of whom explains that "[t]he importance of the replevin laws dwindled and faded away before the passions aroused in the conflict between the legislature and the courts." 137 Crystallization of the conflict was also evident to the legislature, which declared in a January 1825 resolution soon after the Reorganization Act that "an issue was distinctly formed between the two departments, and referred to the People, that august and paramount tribunal, from whose decision there can be no appeal by either party."138

The final decision of significance in the weeks following the reorganization bill's passage was one made by the freshly deposed oldcourt judges, and their choice produced the strangest consequence of all. The judges decided to ignore the statute that purported to abolish their seats. Despite drawing no salaries for their work, they continued to sit and hear appeals throughout 1825 , even handing down several decisions in November. ${ }^{139}$ Meanwhile, the new state high court heard and decided seventy-eight cases that same year. The resultant jurisprudential schism was unique in American history and gave rise to a series of unusual events that heightened the existing political tension in the state. Claiming to be the rightful judicial authority, the new court demanded that the old court release all of its records to the new institution's custody. When the old-court judges refused, the new-court clerk, Francis Blair - an important young journalist in the state risked a violent confrontation by staging a late-night break-in through a window in the old-court quarters to obtain the records. ${ }^{140}$ Across the state, groups of judicial review supporters decried the legislature's Reorganization Act and attacked the legitimacy of the new court. In an interesting exercise of dissident local constitutionalism, they even obtained county grand jury indictments against the new-court judges and various state legislators. ${ }^{141}$ One such indictment, handed down by the Union County grand jury, declared "the most indignant censure of all the good people of the commonwealth" and expressed its "abhorrence

\footnotetext{
137 STICKLES, supra note 33 , at 40.

138 A Preamble and Resolution in Relation to the Decisions of the Court of Appeals, r824-1825 Ky. Acts 221,221 [hereinafter Court of Appeals Decisions Resolution].

139 See I COLLINS, supra note 34 , at 31-32; STICKLES, supra note 33 , at $78-79$.

140 See STICKLES, supra note 33 , at 69.

141 See 2 CONNELlEy \& COULTER, supra note 33, at 637; STICKLES, supra note 33, at 69-70.
} 
of such conduct."142 New-court advocates responded in kind, empanelling their own grand juries in hospitable counties; these juries, in turn, censured the old-court juries for "prostitut[ing] . . . the dignified functions of a grand jury to base electioneering purposes." 143

The simultaneous existence of two high courts also presented the state's appellate bar with unique opportunities for intrajurisdictional forum shopping. It appears that, despite the bar's overwhelming ideological support for the old-court judges (530 of 580 attorneys in the state were aligned with the old-court party), ${ }^{144}$ many attorneys argued cases in both legal institutions. Most of the state's lower court judges certified appeals to both courts during I825 - perhaps as a political bet-hedging strategy, or perhaps at the behest of appellants seeking the most advantageous forum. ${ }^{145}$ Nonetheless, as the crisis played out, Kentuckians came to recognize that the existence of competing courts was incompatible with political or jurisprudential stability. "It is painful, indeed," wrote the new-court judges, "to witness the novel and afflicting spectacle of two sets of men claiming to be Judges of the Court of Appeals, under a government whose constitution knows but one such tribunal." 146

During this period of competing courts, the two sides of the debate waged an ongoing public campaign directed at the critical statewide elections of August 1825 . Several dozen periodicals spread the competing visions of judicial review and legislative sovereignty that divided the state. George Robertson later opined that "[n]o popular controversy, waged without bloodshed, was ever more absorbing or acrimonious than that which raged, like a hurricane, over Kentucky for about three years succeeding the promulgation of those judicial decisions." ${ }^{147}$

The August 1825 legislative election provided a key victory for the old-court party - and thus was a definitive early step toward the ultimate retrenchment of judicial review. Old-court candidates won sixty-two of the general assembly seats, to only thirty-eight for the new-court party. ${ }^{148}$ This newly elected legislative majority immediately set about repealing the Reorganization Act, and with it the new court, but this effort was vetoed by Governor Desha, whose term ran

142 2 CONNELley \& COULTER, supra note 33, at 637 (quoting ARGUS, May 4, 1825 ).

143 Id. (quoting ARGUS, Apr. 27, I825).

144 See 2 CONNELlEY \& COULTER, supra note 33 , at 637 .

145 See STICKLES, supra note 33, at 79-80 ("One obvious conclusion is that [circuit judges] rather feared to take sides definitely on account of the uncertainty of the politics of the time and because the guarantee of holding their positions for life and good behavior . . . had been demonstrated not to mean much.").

146 Id. at 94 (quoting An Open Letter by the Four Neq-Court Judges, THE REPORTER (Lexington), Jan. 30, I826).

147 ROBERTSON, supra note 7 , at 50.

148 See STICKLES, supra note 33 , at 82 . 
until 1826. New-court partisans, the governor among them, maintained that the 1825 electoral results were tainted by voting fraud, press bias, and other factors, and therefore did not reflect a true popular consensus in favor of judicial authority. ${ }^{149}$ The governor's veto infuriated the old-court advocates and effectively prolonged the debate until August 1826 , when an even larger old-court majority entered office. A few months thereafter, an act to repeal the Reorganization Act was signed into law, and the state's political regime returned to something closer to normalcy.150 A fitting epitaph was penned by Hezekiah Niles, an ardent critic of the new-court position, who sardonically wrote in his widely read Weekly Register that "we congratulate our fellow citizens of Kentucky that they again have only one court of appeals." 151

\section{Power, Legitimacy, AND Constitutionalism}

Had the judges the power of judging the laws, nothing could be law but their will; they would be more than kings; they would be dictators, despots, and the people would be their slaves. ${ }^{152}$

The qualified independence of the judiciary is the most important feature in the constitution. Without it, the constitution would be an inert mass, destitute of life, or forms, or comeliness. It would be a chaos of power. ${ }^{153}$

Almost every debate about the judicial review power is, in some important sense, also a debate about the normative attractiveness of majority rule. In a regime founded on democratic self-governance, the vesting of important constitutional authority in an unelected judiciary is justified, if at all, solely as a corrective device that remedies problems arising from the ordinary operation of politics. This underlying premise was understood and made express by both sides in the Kentucky judicial review debate, which quickly became a broader theoretical disagreement over the proper nature of American democracy. Even half a century after independence, the Kentucky crisis revealed a profound public disagreement over what form of democratic government was most desirable in the United States.

149 Opponents of judicial review maintained that the state press favored the supporters, in part because of the latter's greater financial resources. Said one new-court journalist: "[O]ut of 25 or 28 papers printed in Kentucky, there are 18 or 20 arrayed in solid union against her rights... . [A] few individuals, possessed of wealth and ambition, are attempting to controul the people, through the press." The Press, Ky. GAZET TE, Apr. $7,1825$.

150 See An Act To Remove the Unconstitutional Obstructions Which Have Been Thrown in the Way of the Court of Appeals, 1826-1827 Ky. Acts ${ }_{3} 3$ (repealing the Reorganization Act).

151 Kentucky, 3 I NILES' WKLY. REG. 324, 324 (1827).

152 LIBERTY SAVED, supra note 6, at I.

153 PlEBIAN, supra note 12 , at 126. 
In Kentucky, the disagreement inhered in several questions relating to the structural allocation of governmental authority, and to the proper locus and methodology of constitutional interpretation within that framework. All agreed that "the people" were ultimately sovereign, but they disagreed about how to operationalize that sovereignty and how a written constitution constrained it. Was majority will ascendant, or did inviolable individual rights limit popular discretion? What content did such rights have, and who defined them? What was the proper relationship between public officials and the public they represented?

The Kentucky rhetoric illuminates these and other inquiries. The contentious rhetoric and divided popular election results in Kentucky reveal that even two decades after Marbury, the legitimacy of judicial review was far from settled. Significant portions of the public in that part of America refused to accept the unelected judiciary's supremacy, or even its coequal participation, in the project of constitutional interpretation. But the theory of legislative supremacy that judicial review opponents adopted took on an extreme cast that, if election results are any indication, ultimately alienated the median part of the Kentucky electorate. As this oppositional rhetoric became more radical, the position that supporters of judicial review articulated became more moderate. They succeeded in popularizing the rhetoric of judicial rights protection to include noneconomic rights, in recasting the polarity of the conflict from a clash between the judges and "the people" into an interbranch dispute between the judiciary and an unfaithful legislature, and - perhaps most importantly - in persuading the voters that a meaningful public role in constitutional discourse could coexist with judicial review.

The discussion that follows consists of two sections. The first section analyzes competing visions of how properly to distribute "the people's" ultimate sovereignty within a workable government, as well as related disagreements over the legitimacy of independent judicial authority and the importance of protecting minority rights. The second section explores related - and more specific - questions that arose during the Kentucky debate about the distinction between ordinary law and the constitution, and about the proper methods for interpreting the latter.

Two disclaimers are in order at the outset. First, this is not an originalist essay, in that it does not seek to resolve current constitutional debates by locating fragments of authority in the historical positions described here. ${ }^{154}$ The insights that emerge from this controversy

154 And, of course, this episode took place thirty-five years after the framing, so it is not even "original" in any strict sense. 
may inform our consideration of constitutional theory and history in interesting ways, but they compel no specific conclusions on these matters. Second, the relationship between political speech and individual thought is complex and rarely transparent. As with any historical writings, the rhetoric summarized here is evidence of what these earlynineteenth-century Americans said in the course of a contested political campaign, not necessarily what they thought. The instrumental character of political speech may foreclose direct insight into the speaker's thoughts, but it permits a different sort of inference about the perceived attitudes of the audience of that speech. Political speech is an exercise in social persuasion - never more so than where, as here, the stakes are high, the polity is divided, and an election looms. We can assume that professional politicians and partisan journalists then, as now, were reasonably good at formulating their arguments to resonate with the public's intellectual and emotional concerns. In this sense, it is a fair assumption that the arguments expressed in the Kentucky debate about a world with too much judicial review, or about a world with not enough, give a reasonable sense of general public attitudes on these issues in that place and time. ${ }^{155}$

\section{A. Competing Structural Theories of Sovereignty}

The Kentucky new-court party offered a variety of objections to the judicial role in constitutional interpretation. These criticisms of judicial authority were situated within, and in important ways were derived from, a broader structural theory about majoritarian governance and popular sovereignty. Central to that theory was the goal of keeping as much ongoing decisional authority close to the public as possible - a goal that was in obvious tension with the notion of judicial review by unelected judges. This placement of constitutionalism within the broader hydraulics of sovereign power is itself telling, for it reflects a characterization of constitutionalism as an exercise of power very different from the ordinary legal adjudication in which judges typically engaged during the early nineteenth century.

I. Questions of Representation. - Like most Americans in the early republic, one thing upon which both sides in the Kentucky debate did agree was that "the people" were sovereign in some foundational sense. This principle was instrumental in generating support for the U.S. Constitution despite prevailing notions about the indivisibility of sovereignty, but it did not help much in operationalizing govern-

\footnotetext{
155 Because the arguments were directed at an election in which all white males could vote and most could read, the rhetoric here better captures a range of public attitudes than does the discourse among elite politicians that characterized the national debate over judicial review. For a discussion of the differences between national and state debate on the issue in this era, see infra section III.C, pp. 892-94.
} 
ment in practice. The central problem for any theorist of democracy is how to translate belief in the sovereignty of "the people" into an actual governing regime, and the primary vehicle for doing so is some method of representation that translates popular sovereignty into actual policy. The Framers' vision of representation is relatively well-known, but it is worth summarizing one aspect of the constitutional debate before examining the alternative vision that the Kentucky opponents of judicial review offered. Madison's formulation was to accept representation not merely as necessary for government to operate, but as itself a positive good, allowing for the intercession of the representatives' independent judgment and virtue in the legislative process. ${ }^{156} \mathrm{~A}$ model of representation that separated officials from their constituents was desirable, in J.G.A. Pocock's words, because it "moderated the violence of democracy by rendering it indirect." 157 Representation both facilitated and improved the enterprise of governance by allowing the independent judgment of a political elite to bear on policy decisions.

The Kentucky opponents of judicial review rejected the notion that representation offered its own normative reward. For them, representation was inherently problematic in that it placed the people's decisional authority in the hands of a set of official agents. ${ }^{158}$ It was an evil necessary for governance, but an evil nonetheless, and so rather than celebrate representation and create structural space for the exercise of independent discretion, they sought ways in which to impose tight limits on representatives' latitude to deviate from popular will. In this view, the potential for separation between the people and their representatives should be as small as possible - both temporally, through holding annual elections, and conceptually, through cabining legislative agents' discretion. This theory of representation was rooted in the English Leveller tradition of the sixteenth century, and it borrowed from the conceptual framework and rhetorical lexicon of agency law. ${ }^{159}$ The people were the "masters" in this hierarchy, and the government officials were their "servants" or "agents." According to a resolution passed by the Kentucky legislature at the height of the controversy, the constitution

\footnotetext{
156 See THE FEDERALIST No. Io (James Madison) (explaining the advantages of a republic over a democracy).

157 J.G.A. Pocock, States, Republics, and Empires: The American Founding in Early Modern Perspective, in CONCEPTUAL Change AND THE CONSTitution 55, 70 (Terence Ball \& J.G.A. Pocock eds., I988).

158 This theory indirectly reflected Rousseau's doubts about the basic legitimacy of representation. See, e.g., Hanna Fenichel Pitkin, Representation, in POlitical INNOvation AND CONCEPTUAL ChANGE 132, 149-50 (Terence Ball et al. eds., I989).

159 See generally Michael Kent Curtis, Judicial Review and Populism, 38 WAKE Forest L. REv. 313, 337-42 (2003).
} 
is a power of attorney made out by the corporate and moral person, civil society, designating the legislative and executive agents, and prescribing and defining their powers and duties. . . . [The public,] in its character of sovereign, superintends, watches and controls its agents, according to the mode which it has prescribed to itself in the constitution. It holds all its functionaries strictly responsible for the faithful discharge of their duties ... 160

The idea that it was necessary to "watch[]" and "control[]" public officials and to hold them "strictly responsible" for the proper discharge of their duties shared a basic assumption with the Madisonian model, but came to a very different conclusion. Along with early Americans' general theoretical agreement about the ultimate sovereignty of the people, there was also a consensus that it was possible for the representatives to betray the people. ${ }^{161}$ One solution to this problem is well-known, for it prevails today: it was to vest coordinate oversight in the various branches of government. As the Kentucky oldcourt advocates explained in defense of judicial review, tripartite "harmony" and "equilibrium" were critical to enable each department to check the transgressions of the others. ${ }^{162}$

Kentucky opponents of judicial review, however, sought to vest oversight authority unambiguously in the public rather than in other branches of government, with obvious negative implications for the legitimacy of robust judicial review. Because the people closely superintended their agents in the legislature, it was acceptable to vest power, and lots of it, in that branch. As the legislature in Kentucky resolved: "The people take their representatives to account annually, and test the fidelity of their agency, that they may the more safely confide to them ...." 163 Contrary to Madison's fears that the legislature would be the most dangerous branch of government, ${ }^{164}$ the legislature was the least dangerous branch, because it was the one most directly subject to popular control. In the agency paradigm, the real danger of government was not how much power a particular branch exercised, but rather the degree to which that power was uncoupled from popular electoral control. The implication of this view became express in the debates over judicial review: it was unsafe and inappropriate to vest much authority in any part of the government that the people did not directly control.

All of this rendered judicial review both unnecessary and illegitimate in the eyes of new-court advocates. If the people were closely

\footnotetext{
160 Replevin Laws Resolution, supra note $\mathrm{I} 20$, at 250.

161 See generally WOOD, supra note 25 , at $162-96$.

162 See PleBIAN, supra note 12 , at I 23.

163 Replevin Laws Resolution, supra note 120 , at 250.

164 See THE Federalist No. 48, at 333-34 (James Madison) (Jacob E. Cooke ed., 1961).
} 
watching the legislature to ensure its fidelity to popular will and general constitutional principles, it was unnecessary for the judiciary to do so. Opponents of judicial review made this point in the Kentucky debates, asking what role the judiciary could play that added much to the people's active superintendence. Countering old-court party arguments about the importance of judicial independence in the AngloAmerican tradition, the legislature responded that the liberties historically enjoyed by Englishmen were attributable to the people, not the judges. They were "the irradiations of the confluent will of ten millions of people, and not the twinkling scintillations of the [i]ndependence of the twelve Judges and the Lord Chancellor." 165

Judicial review was worse than superfluous, though. To the extent that it conflicted with the public's interpretive oversight, it was fundamentally subversive of proper government. Because the public's oversight of the legislature was theoretically ongoing, judicial invalidation of a popular law constituted an improper repudiation of the interpretive judgment of the people. "Is not the tendency of this doctrine [of judicial review]," asked the legislature, "to reverse the order of nature, and make regents of the agents, and vassals of the people?"166 When the court of appeals struck down the replevin laws, one newcourt partisan wrote, "these servants, established only to judge our suits according to law, and expressly prohibited from interfering with legislation, broke these laws." 167 According to critics of judicial review, the judges on that court were "unfaithful servants" who had illegitimately interfered with democratic rule and were accordingly "turn[ed] . . out of office" by the voters. ${ }^{168}$

Judicial review, in this perspective, violated the basic downward flow of authority in the agency theory of government. The judicial role in such a paradigm was narrowly confined to applying the law, not inquiring into its constitutionality:

[W]e appoint judges . . . but it is never understood that they will judge our laws, because to vest them with such a power, would be to put them over our will, over our laws, and, if elevated over our will, over our laws, in-

\footnotetext{
165 Replevin Laws Resolution, supra note 120 , at 249 . The legislature proclaimed that the revolutionary generation's grievance "was not ... the dependence, but the independence of the judiciary." Id. at 248; see also SPEECH OF SAMUEL DAVEISS, ESQ., supra note 95 , at 4 ("[W]e are too much in the habit of considering our government like that of Great Britain, where the independence of the judiciary is the only security that the people have against the encroachments of the crown.").

166 Replevin Laws Resolution, supra note $\mathrm{I} 20$, at 273; see also LIBERTY SAVED, supra note 6, at 16 ("And where is the dictionary, where is the language in which there is such a change, in which the word servant signifies master, and the word judging signifies overlegislating, or even only making laws?").

167 LIBERTY SAVED, supra note 5, at 9.

168 Id.
} 
stead of being only our servants, to judge our suits according to law, they would be our legislators, our masters, our dictators, our sovereigns . . . ${ }^{169}$

Clearly, this was not a theory of government that prioritized a balance of powers. This vision stressed clarity and directness, both in the public's oversight of the legislature and in the legislature's dominance over the rest of government. Explained new-court politician Samuel Daveiss, "our government is not so much a balance of power, as a well connected chain of responsibility." 170 In this framework, the judiciary (and the executive, for that matter) was not a coordinate branch, but a subordinate one. Echoing earlier Antifederalist critiques of splitting the people's sovereignty into two governments, state and federal, the new-court party denied the possibility of a meaningful tripartite separation of powers within the state government. "[I]n every government," said the legislature by resolution, "there must exist a controlling and paramount power, competent to all the purposes of government; ... [and] all other lodgments of power must be subordinate." ${ }^{171}$ The "controlling and paramount power" in this regime was the legislature, composed of delegates "elected expressly and exclusively to make" laws. ${ }^{172}$ Legislators "are the people themselves by representation, or at least the first class of their servants. The Judges, a second class, appointed by parts of that first one, have nothing to do but to judge suits and maintain peace according to the laws made by that first one."173 The legislature was thus entrusted with the power to control the other branches of government. ${ }^{174}$

This linear, hierarchical thinking may partially explain why the new-court party did not advocate a more moderate position and seek to reform the system - for example, by making judges elected, as many states, including Kentucky, would do over the next few decades. Vesting authority to review legislative acts in the judiciary, even one accountable to the public in periodic elections, interfered with the linear hierarchy of this agency theory of government, under which "there must exist" a single "controlling and paramount power." 175

\footnotetext{
169 Id. at 17.

170 SPEECH OF SAMUEL DAVEISS, ESQ., supra note 95, at 5

171 Court of Appeais Decisions Resolution, supra note $\mathrm{I} 38$, at 222.

172 LIBERTY SAVED, supra note 6 , at 16 .

173 Id.

174 See id. ("In the civil government, the legislator issues the laws, the judges are not to control them; they are to obey them and to make the citizens obey them.").

175 Court of Appeals Decisions Resolution, supra note 138, at 222. And the fact of life tenure made the judiciary an even more illegitimate repository of independent power: "[I]t never could be expected, that because a prudent division of the powers of the govemment was made, all things would go on well, without accountability on the part of those who were intrusted." SPEECH OF SAMUEL DAVEISS, ESQ., supra note 95, at 5 (emphasis added).
} 
2. "[I]n ... a multiplicity of checks the freedom of the whole will be safe." 176 - Supporters of judicial review in Kentucky disagreed profoundly with the hierarchical model of legislative supremacy described above. Their theory emphasized a tripartite balance in the allocation of governmental authority, and a prominent role for the judiciary in supervising the constitutionality of legislative acts. "The great principle of America," said one judicial review supporter, "is the appropriate distribution of the functions of government, among three coequal departments."177 The reciprocal checks carried out by each department created an equilibrium of authority, and "[i]n this equilibrium of power lies the value of a constitution."178 The old-court judges themselves were important proponents of this view, and in a speech to the legislature, they offered a widely publicized defense of judicial authority. Rejecting the theory of legislative supremacy, the judges argued that "it is not to that department alone, that the people have entrusted the administration of their government, and confided the protection of all their rights." 179 Rather, they have "divided the government into three separate departments... making each coordinate with, and independent of the other; and from each have required an expression of opinion, as to the constitutionality of law, before that law can be enforced upon them."180

Important in this formulation was the idea that the three departments were coequal and coordinate, and "properly balanced, with the power and the inclination to co-operate with, or counteract each other when the public good requires." 181 The new-court party's subordination of the judiciary as a "second class" of public officials undermined this carefully designed equilibrium. Said old-court legislator George Robertson: "[E]ach of the three departments is created by the constitution, and whenever either becomes the creature of another, the theory of the constitution is subverted, and the government revolutionized ...."182 To the old-court judges, the new-court party's monistic theory was an illicit attempt "to blend the powers of government, and place in legislative hands the control of all."183 Judicial review supporters were unwilling to accept such violence to their balanced system of government, asking: "Are we to turn a deaf ear to the commanding voice of the constitution, and become the subservient instruments [of

\footnotetext{
176 RESPONSE OF THE JUDG ES, supra note I 2 I, at 3 I.

177 PLEBIAN, supra note I 2 , at 125.

$178 I d$. at I 23.

179 RESPONSE OF THE JUDGES, supra note $12 \mathrm{I}$, at 8.

180 Id.

181 PLEBIAN, supra note I 2, at I 23. 99.

182 GEORgE ROBERTSON ET AL., TO THE FREEMEN OF KENTUCKY (1825) [hereinafter MANIFESTO OF THE OLD COURT PARTY], reprinted in ROBERTSON, supra note 7 , at 97 , IOI.

183 RESPONSE OF THE JUDGES, supra note 121 , at 36.
} 
the legislature] ... ?"184 They answered: "How immoral the thought! How humiliating the idea!"185

This structural debate about judicial and legislative authority overlay a more fundamental disagreement on the relative importance of popular will and individual rights. Both sides in Kentucky recognized this, the one casting judicial review as a necessary protection for minority rights, the other casting it as an illegitimate interference with public will. The question gripping the state, said the new-court majority, was "whether the people shall govern, or be governed by the few, or a still smaller number." 186 The judges and their supporters responded by arguing that occasional judicial interference with legislative will was precisely what the framers of the state and federal constitutions had contemplated. According to the old-court judges, "[m]any highly exalted and worthy patriots" in the founding generation had "felt the injuries which had been inflicted upon the people[] by an omnipotent Parliament ... [and] were unwilling to entrust all their rights to the unlimited discretion of legislative will."187 The framers' constitutional design "displayed all their jealous apprehensions" about legislative excess and "reserved to the people themselves" a set of rights that no popular majority could transgress. ${ }^{188}$ Judicial review supporters scored a political victory when Revolutionary War hero Isaac Shelby entered the debate on their side, writing that the new-court advocates for legislative supremacy threatened "those essential principles of a free government for which we have fought and bled."189

Defenders of judicial review maintained that the new court's emphasis on legislative supremacy put individual and minority rights at imminent risk. They warned that without independent judicial review, "liberty and equality' will be empty sounds[,] ... the ambitious and the powerful will hold in their hands the destinies of our state[, and] . . . the minority will, indeed, have 'no rights." 190 The oldcourt party's "manifesto" proclaimed that "the inviolability of our constitution is essential to the life, liberty, and property of every citizen."191 Meaningful separation of powers was "a three-fold guarantee to the people, against any encroachment upon their rights" by popular majorities, ${ }^{192}$ and in this scheme the judges were "made the peculiar

\footnotetext{
184 Id. at 5 .

185 Id. at 6.

186 Replevin Laws Resolution, supra note 120 , at 277

187 RESPONSE OF THE JUDGES, supra note I 2 , at 4-5.

188 Id. at 8 .

189 Doolan, supra note I 28 , at 636 (quoting a letter from Shelby).

190 PROTEST OF THE MINORITY, supra note 7 , at 93

191 MANifesto OF THE OLd COURT PARTY, supra note I82, at IoI

192 RESPONSE OF THE JUDGES, supra note 121 , at 8.
} 
sentinels to guard the constitution" and the rights it protected. ${ }^{193}$ Without this judicial check, the tyranny of majority rule had unlimited potential. As old-court legislator George Robertson stated in one of his "Plebian" letters to the governor-elect of Kentucky:

[I]ndividual rights [are insecure] in a government in which the will of an ascendant party is in all cases the supreme law. No government can be free or stable, unless the principles of justice and morality overrule the passions or interests of factious bodies. A truly free government is one in which justice predominates over power, and right over might. No government is free or equal in which power is justice, and might is right, although that power is the authority of numbers, and that might is their physical force. ${ }^{194}$

The opponents of judicial review had several responses to these alleged failings of majority rule and the correlative idea that judicial review was needed to protect individual and minority rights. First, without conceding that a majority could ever violate reserved minority rights, the new-court advocates did acknowledge the possibility that the public could act rashly. ${ }^{195}$ But they claimed that the constitutional provisions creating and governing the legislature provided ample safeguards against sudden or unwise lawmaking. Speaking of the public's vote in favor of judicial review opponents in the 1824 elections, the legislature explained that "[the public's] opinion is not the effervescence of popular excitement; it is the result of a deliberation, calm and dispassionate in a degree proportioned to the magnitude and importance of the question." 196 New-court advocates minimized oldcourt concerns about legislative tyranny by asserting that the "collective wisdom of majorities" would secure the liberties of all members of society. ${ }^{197}$

As explained in more detail in the next section, critics of judicial review offered another functional critique of the old-court party's rationale for judicial protection of rights. Even accepting, arguendo, the claim that some rights should be protected from majoritarian intrusion, the new-court supporters denied the judiciary's competence to draw this line.

\footnotetext{
193 Id. at Io.

194 PLEBIAN, supra note I2, at $122-23$

195 See Court of Appeals Decisions Resolution, supra note I 38, at 224, 227 (acknowledging that some level of restraint on legislative power was necessary).

196 Id. at 22 I

197 LIBERTY SAVED, supra note 6, at 4. The Reorganization Act, which dissolved the state court of appeals in response to its efforts to secure the rights of certain members of society, is perhaps evidence that undermines this claim about existing structural safeguards, but other concurrent political events support it: removal of the judges by address was defeated by a sufficient minority of holdover senators, and when the political winds shifted in the election of 1825 , it took over a year (and another election in 1826) for judicial review supporters to repeal the Reorganization Act and reinstall the original court of appeals.
} 
Critics of judicial review went far beyond these functional arguments, however, and advanced a much more fundamental, theoretical argument. A strand of their rhetoric denied altogether that there were any individual rights set off from the majority's exercise of its sovereign will. Popular will was supreme, and rights reserved against it were both unnecessary and illegitimate. The "confluent will" of the public was "the unerring arbiter and uncontrolled sovereign of the State. It is this will, and this alone, which imposes, in the constitution, the only check upon legislation which it can recognize, or to which it can submit." 198 Judicial review was not needed to secure personal rights "in our Republican government ... because the people cannot be their own enemies."199 Pushed to its theoretical limits - as it was by the legislature in late I 824 and I 825 - this absolutist conception of majority rule denied all legitimacy to minority rights. The legislature resolved:

All that is said [by the judges] . . . about the rights of minorities, is incompatible with the very nature of civil society. . .

The rights of each member of society, must, from the nature of government, depend upon the will of all, and that will must be displayed by the agency or expression of the majority. The rights of all are equal, homogeneous and correlative, and depend alike upon the general will. The majority is the channel through which the stream of that will must, to be efficient, flow. The minority is the divergent tendency of a portion of its volume, which, by meeting with resistance in its lateral direction, forms a temporary eddy, and again disappears by its confluence with the general stream. The presumption is, always, that the minority is wrong; and the only right which it has, is to escape from that imputation, by endeavoring to become, through its enlargement, the majority, and in its success, to lose, with its existence, its right. ${ }^{200}$

The majoritarian absolutism inherent in the foregoing statement is striking, and if the language is jarring to modern readers in a postCarolene Products ${ }^{201}$ world, it was also troubling to many observers at the time, both inside and outside of Kentucky. ${ }^{202}$ Such extremism may have been bad politics, too, for the extremism of the legislature's sovereignty claims probably gave additional traction to the old-court party's warnings about majoritarian tyranny - - warnings that, in turn, helped produce old-court electoral victories in I 825 and 1826 .

3. "Aristocrats" and "Farmers." - There is, however, a contextual explanation that somewhat mitigates the severity of this rhetorical de-

\footnotetext{
198 Court of Appeals Decisions Resolution, supra note 138, at 223.

199 LIBERTY SAVED, supra note 6, at 21 note h.

200 Court of Appeals Decisions Resolution, supra note 138, at 223.

201 United States v. Carolene Prods. Co., 304 U.S. I44, I 52 n.4 (I 938 )

202 See infra section III.A.2, pp. 88I -84 , for a discussion of the recorded views on the Kentucky crisis expressed by national leaders, almost all of whom supported the old-court position.
} 
nial of minority rights. The widely shared premise in the debate over minority rights in Kentucky - and elsewhere in America - was that the "minority" at issue was the economic and social elite, and the "rights" in play were those of property and contract. ${ }^{203}$ Many of Kentucky's wealthiest citizens, and most of those in its professional and social elite, were aligned with the old-court party's support of judicial review. For example, a vast majority of Kentucky attorneys practicing at the time supported the old-court platform. ${ }^{204}$ A new-court pamphlet reported that among key supporters of the old-court judges, "there were no poor men; none who know what it is to want, to suffer, or to need relief."205 Rights-protection rhetoric in old-court literature was perceived by new-court supporters as a device to protect economic and social privilege. Occasionally, the connection was more express: Humphrey Marshall, a prominent landowner and cousin of the Chief Justice, had written a few years earlier in favor of significant property qualifications for voters who would elect the state senate, asserting that the state constitution should protect "the rich" and "the aristocracy," as well as "the poor" and "the democracy," from the "passions[] or ... antipathies of each other."206

New-court advocates were keenly aware of this socioeconomic undercurrent of the theoretical debates, and they shaped their discourse to exploit class divisions. One pamphleteer asked rhetorically:

Have we no aristocratic spirit in our country? no wealth which spurns the laborious throng, from which it has derived its imposing grandeur? no "talented minority" which looks down with supercilious scorn, and claims a controul over the multitude of little men, which it presumes to consider as fashioned by nature for its use? ${ }^{207}$

Such an "aristocratic" minority had existed for some time in the American republic, according to the new-court politicians, and a central feature of their scheme to wrest power from the people was the institution of judicial review. ${ }^{208}$ "[T]he talented and monied aristocracy of our country," wrote" the pseudonymous "Lafayette," had "fondly hoped that through their influence and connexion with a judiciary in-

203 Cf. The Federalist No. Io, at 59 (James Madison) (Jacob E. Cooke ed., I96I) (asserting that the divisions between property owners and those without property, and between creditors and debtors, are among the leading causes of political faction).

2042 CONNELLEY \& COULTER, supra note 33 , at 637.

205 BANK DINNER, supra note 39 , at 25-26.

206 I HUMPHREY MARSHALl, THE HISTORY OF KeNTUCKY 426 (Frankfort, Ky., Gerrge B. Robinson 1824 ).

207 LAFAYETTE, supra note 37 , at 7.

208 In the new court account, this political aristocracy was traceable to Hamilton's influence in American constitutionalism. See BANK DINNER, supra note 39, at ro ("[A] fragment of monarchy, presented by Alexander Hamilton, was 'adroitly smuggled' into the constitution of the United States in the form of a Judiciary for life ....,"). 
stalled for life and independent of the people, they would be enabled to control the legislation of the people ... and thus temper the democratic features of our institutions."209

Wealthy individuals were aligned in "support of a power, which has conferred such peculiar privileges on incorporated wealth,... [and] which, in conspiring to destroy the force of the public will, gives to the rich, the great, the landed and monied gentry . . . hopes of deliverance" from democratic rule. ${ }^{210}$ According to new-court rhetoric, the economic and social stature of the old-court partisans bred an elitist intellectual arrogance that disparaged popular opinion: "[I]n the opinion of these men, th[eir] knowledge and talents entitle them, with the aid of two or three judges, to govern the country." 211

An additional strand of this new-court rhetoric focused on the professional elitism of the lawyers and bankers who tended to support the reestablishment of judicial review. Writing as "Jefferson," Francis Blair told the public that the judges "rallied around [them] the power and influence of the state and national banks, of most of the lawyers, of the merchants, of the rich, of the non-residents and idle chatterers who infest our towns." 212 New-court pamphleteers took to calling the old-court party the "lawyer party," the "lawyer faction," or the "court party," the latter label enabling new-court writers to assume the mantle of the "country party," thus getting a bit more mileage from a wellworn political idiom of previous generations. ${ }^{213}$

This socioeconomic subtext presented a substantial political challenge to judicial review supporters seeking retrenchment in a popular election. If the electorate accepted the new-court party's characterization of individual rights as a special interest of the propertied elite, the judges and their supporters would be unlikely to prevail in the general elections of 1825 and 1826 . Thus, it would be a great success for supporters of judicial review to frame the discourse about rights so that it appealed more broadly to the voters.

The old-court politicians democratized their defense of judicially enforceable rights with two related arguments. The first was a defense of property rights writ small - that is, they stressed the legislative danger to those property and contract rights that were important to

\footnotetext{
209 LAFAYETTE, supra note 37 , at 36.

210 Id. at 12 ; see also id. ("Let the people look around and they will find in the classes here presented ... the friends of the old court. It is the audacity of those privileged persons, which has emboldened that court to attempt a judicial repeal of Legislative enactments . ...").

213 For a concise and thoughtful discussion of the Court-Country division in English and early American political thought, see STANLEY ELKINS \& ERIC MCKITRICK, THE AGE OF FEDERALISM I3-29 (1993).
} 
the entire population. Recourse to the judiciary was not just for the rich but, in the campaign rhetoric of the judges, available to everyone, "however humble his condition or small his influence." 14 The rights of all were at risk "where that judiciary has not the power to rescue the humble or persecuted citizen from the oppression of an ambitious and rapacious faction." 215 Similarly, the old-court party's legislative protest of the Reorganization Act warned that "[t]his example will consecrate every encroachment that power can make on the rights of the poor and the humble, the persecuted and the virtuous." 16 Even the pseudonym "Plebian" that George Robertson adopted in a series of published letters setting out the old-court position reflected his party's rhetorical efforts to neutralize the public's prevailing socioeconomic assumptions. ${ }^{217}$

A related strategy for countering the new-court party's class-based critique of judicial review was to define the rights set off from majority control as including not just property and contract rights, but also a range of noneconomic liberties. For example, George Robertson warned voters that if judicial review were eradicated, "the freedom of speech and of conscience, and the rights of life, liberty, and property, will depend on the caprices of a fluctuating majority of the legislature."218 Among the many successes of the Kentucky judicial review party's political rhetoric was the broadening of its rights discourse beyond the realm of property and contract to the (then) more hypothetical issue of noneconomic liberty. To the degree that majoritarian excess could be seen as a danger to all, judicial review was correspondingly more popular.

Just as the judicial review supporters succeeded in popularizing the terms of discourse about rights, they were able to recast the controversy from a clash between unelected judges and "the people" into an interbranch struggle between the judiciary and the legislature. "The legislature are not the people," stressed Robertson in one of his pseudonymous letters; "they only represent the people in the faculty of making laws." 219 The legislators were capable of betraying the people's constitutional mandate, ${ }^{220}$ and when they did so, an independent

\footnotetext{
214 RESPONSE OF THE JUDGES, supra note $\mathrm{I} 2 \mathrm{I}$, at 7.

215 PLEBIAN, supra note 12 , at 126.

216 PROTEST OF THE MiNORITY, supra note 7, at 93; see also PLEBIAN, supra note I 2 , at I26 (insisting that the constitution's inviolability "will endear it to the poor tenant of the humble cot").

217 See, e.g., Plebian, To The Governor Elect OF KENTUCKY - No. I, reprinted in ROBERTSON, supra note 7 , at I05.

218 PROTEST OF THE MINORITY, supra note 7, at 93.

219 PLEBIAN, supra note $\mathrm{I} 2$, at I 23.

220 George Robertson suggested that legislators, by virtue of their character, were more likely to betray the public than were judges: "The ambitious man, who meditates supreme sway over his country's destinies, never mounts the Bench. He mounts the 'stump,' and winds himself into
} 
judiciary was instrumental to preserving the higher-law structure of society. Coopting the agency law lexicon of the new-court partisans, the old-court judges explained that "the judges act as the people's agents . . . in expounding the constitution, and in pronouncing the invalidity of all acts of the legislature which come in collision with it."221

\section{B. The Locus and Methodology of Constitutional Interpretation}

The foregoing discussion has explored the contours of disagreement in the Kentucky court crisis over broad theories of governmental structure and the legitimacy of meaningful judicial review authority in a republican political regime. This struggle also raised more specific, but no less fundamental, questions about the meaning and practice of constitutionalism. What constraints, if any, did a written constitution impose upon ordinary public policymaking? Which was the most legitimate, or competent, group to interpret the constitution and discern those limits: the judiciary, the legislature, or the public? Should the constitution be construed by employing "legal" methodology, or was a different methodology more appropriate? Was the constitution "supreme ordinary law," or was it a form of "higher law" to be construed under different rules and by different people?

These questions are particularly relevant in light of Larry Kramer's recent exploration of similar ones in his broader historical study of early American constitutionalism. ${ }^{222}$ Kramer argues that early Americans conceived of the constitution as fundamentally different from ordinary law, and that the public itself engaged in a type of higher lawmaking by interpreting the document. ${ }^{223}$ Much in the discourse of the Kentucky crisis supports Kramer's thesis. Both parties to the struggle regarded the constitution as not only supreme to ordinary legislative enactments but also as different in kind, with different interpretive consequences. Both acknowledged that the public was an important interpreter of the constitution. Unsurprisingly, new-court advocates placed constitutional interpretive authority squarely in the hands of the people, and they expressly denigrated legalist modes of construing the document. Even supporters of judicial review, however, acknowledged a significant public role in constitutional discourse, albeit one

\footnotetext{
public favor, by flattering the prejudices and passions of the majority, as the serpent decoyed Eve." George Robertson, Speech Against Resolutions Condemnatory of the Court of Appeals in Kentucky (Dec. 4, 1823), in ROBERTSON, supra note 7, at 49, 59.

221 RESPONSE OF THE JUDGES, supra note $12 \mathrm{I}$, at 8 ; see also id. at 30 (explaining that the constitution divides power among "three separate kinds of agents[, each with] a paramount law hanging over him when he sits in his official seat").

222 See Kramer, supra note s; see also KRAMER, supra note 5.

223 Id. at Io ("The Founding generation['s] ... Constitution was not ordinary law, not peculiarly the stuff of courts and judges. It was ... a special form of popular law, . . qualitatively different from (and not just superior to) statutory or common law.").
} 
that left room for the courts to share interpretive authority. The two successive state elections that reestablished judicial review in Kentucky ultimately expressed the public's constitutional judgment on the merits of the doctrine.

1. The New Court's Populist View of Constitutionalism. - (a) Judicial Illegitimacy and Incompetency in Constitutional Interpretation. - Much of the rhetoric in Kentucky opposing the judicial role in constitutional construction mirrored the more general obiections to judicial authority explored above: judges had no legitimacy to declare leg. islative actions unconstitutional, because to do so would exalt their subordinate authority over that of the people and their directly accountable agents in the legislature. By situating the illegitimacy of the judicial review power within a broader theory of popular sovereignty, new-court advocates made an important point about constitutionalism: it was an exercise of sovereign will or power, not of ordinary legal construction. "Had the judges the power of judging the laws," declared an important new-court pamphlet, "nothing could be law but their will."224 Formulations like this one were common in new-court rhetoric and illuminate much about that party's conception of constitutionalism. Consider the last two words in the foregoing statement: "Will" equates constitutional review with a discretionary exercise of sovereign authority, not a mechanical and neutral application of legal technique. "Their will" says more - it suggests that interpretative outcomes are dependent on the interpreters' attitudes, rather than fixed and discoverable by judges with sufficient training, wisdom, and impartiality. As a new-court legislator explained, "it will generally be found, that men will be apt to give that construction which accords most with their own interest." 225 Such a characterization went far toward delegitimizing judicial review in the Kentucky contest and carried several related implications for the role of judges in constitutional adjudication.

First, if constitutionalism was a discretionary application of sovereign will, then the people who exercised their will in the realm of ordinary politics were perfectly capable of doing so on constitutional questions. Said the legislature:

[The people] cannot ... have a less zealous interest in the maintenance of the constitution, than the three Judges. They cannot, we think, be decently said not to possess intelligence enough to comprehend its import, nor virtue enough to regard its obligation; nor can they feel themselves

\footnotetext{
224 LIBERTY SAVED, supra note 6 , at I.

225 SPEECH OF SAMUEL DAVEISS, ESQ, supra note 95, at 29. Daveiss made this comment as part of an explanation of why creditors tended to favor stringent Contract Clause enforcement. See id. at 28-29.
} 
flattered, when they are told, that their understanding of its provisions is to be wholly disregarded, in its construction. ${ }^{226}$

Samuel Daveiss expressed a similar view, stating that the Framers' goal was "to hand out to the people of America, an instrument capable of being understood by common intelligence."227 By the same theory, legislative and executive officials were just as capable of constitutional decisionmaking as judges, and probably more so. Judicial interpretation was superfluous: "[W] hat additional wisdom could be that of a few judges to the collective wisdom of all the nation? - Would not the nation, an immense colossus in comparison to the pygmyism of the body of judges, want a microscope to see it?"228

Moreover, because constitutional construction was allegedly so different in kind from the ordinary work of judges, their narrowing techniques of traditional lawyering and judging might actually hinder their interpretive competence. Constitutionalism required a broader vision and set of skills than the judges possessed by virtue of their legal training and experience. "There is not the least need of statistical or political science to be a judge," said the author of a leading new-court tract; "[t]he law is his guide and it is not for him to inquire whether or not it is a beneficent or maleficent one, whether or not it is right or wrong." 229 The judges' "offices are considered as so much less important than those of legislators... [because] it matters not whether or not they are statesmen, whether or not they are acquainted with the wants and interests of the state." 230 Instead, "all that is wanted to be known of their abilities, is whether or not they are learned in law." ${ }^{231}$ These statements are reflective of the early-nineteenth-century distinction between ordinary legal interpretation and constitutional interpretation. ${ }^{232}$ The latter, in the new-court partisans' view, was inappropriately vested in the judiciary.

(b) "That little book": Implications of Writtenness for Popular Constitutional Theory. - This distinction between constitutionalism and ordinary legal interpretation also had ramifications for interpretive methodology. The new-court party criticized efforts by the judges and their supporters to "legalize" the character of constitutional discourse and thereby distance it from popular comprehension and control. "[A] constitution!" exclaimed one pamphlet, "some designing men are misrepresenting it as a mysterious composed thing of causes and

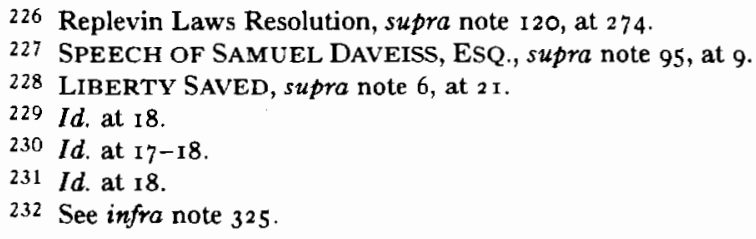


effects, as the whole world; but it is not so; it is a simple thing, very easy to be understood." ${ }^{33}$ Another warned that the people were being "assailed by an army of Judges, armed with constructions," who had "created in their minds a beautiful theory, to which the practice and experience of almost half a century must be compelled to yield." 234 Legalizing constitutional interpretation dishonored the Framers' intent, since they did not make the constitution "exclusively for ... learned men; but for the whole people of America."235 Accordingly, it would "be unreasonable to presume, that they intended to make use of words, the meaning of which, could only be explained by the ingenious or subtle lawyer."236 The jurist who "resorts to metaphysics and law books to sustain constructions hostile to the common understanding of the community" exceeded his "legitimate province of administering the laws."237

Perhaps inconsistently, the interpretive methodology that the newcourt politicians proposed to the electorate contained strains of both textualism and presentism. They frequently quoted constitutional text in their popular appeals and invited the public to read and interpret that text: "I want every one of you to read the proper parts to enable you to judge for yourselves," wrote the author of a pamphlet entitled Liberty Saved, before quoting passages of constitutional text. ${ }^{238}$ Another pamphlet cautioned against the "tricky technicalities of professional perfidy" and urged Kentuckians instead to apply "a plain understanding uninstructed in the refinements of the art of legal legerdemain."239

Juxtaposed against this popular textualism was a more radical strand of discourse that emphasized the malleability of constitutional norms over time, and even diminished the written constitution both as a fixed set of principles and as a supreme historical text. "[I]t will be readily admitted," resolved the legislature, "that the dead have no right to govern the living; and that the dicta of no man, dead or living, should have any obligatory effect upon the mind of another, further than their correctness is recognized by his reason." 240 Similarly, the

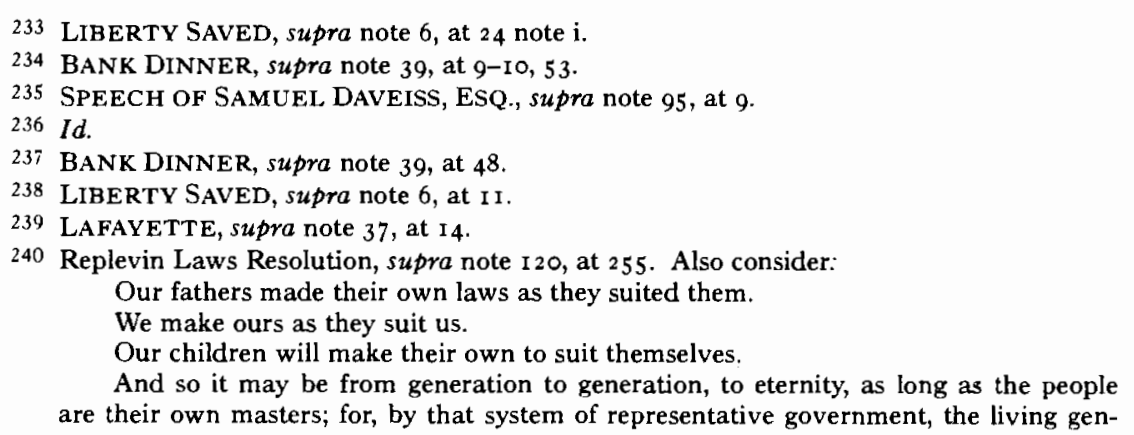


Liberty Saved author declared that "we are willing to continue being ourselves our sovereign, and we are willing to transmit our sovereignty in all to our children, ... each generation of them having the like right of amending its constitutions and laws, as well as ourselves." 241

Supporting this view of diminished constitutional constraint were statements that expressly denigrated the written constitution as a controlling higher law. "[W]hen gentlemen talk of the constitution," said one pamphleteer, "and point to that little book, as containing it, they talk nonsense - the will of the people is the constitution - the Legislature expresses the people's will." ${ }^{242}$ This disparagement of the written constitution had a historical component that emphasized the social compact, not the constitutional convention, as the political regime's most important foundational moment. Said one pamphlet, "[e]ven the truth is that the constitution has not established any thing, it has only determined the ways and means in which every part of the government should be established." 243 When judges struck down the replevin laws, explained another tract, they "destroy[ed] the right of the people ... to provide their own system of remedial justice; a right older than the constitution itself." 244 The legislature expressed this more directly:

The Judges seem not to comprehend that ... the social will is the sovereign power of the State .... When they shall have ascertained by examination and reflection, that there is a real and palpable, not a nice, obscure and doubtful distinction, between the social compact and the constitution, they will comprehend this fundamental and essential truth. They will then comprehend, also, that the legislative power is derived from the people, through the social compact; that the constitution does not originate the legislative power, but pre-supposes its existence, and prescribes the mode in which it shall be exercised, and imposes restraints upon its exercise; and that, by that compact, civil society possessed the power to legislate, adjudicate, and execute, according to its discretion ....245

It is not clear that these disparaging arguments were central to the new-court platform; other statements, including some quoted earlier, emphasized the centrality of the constitution's text and the fixity of certain principles. What was central was the people's role in constitutionalism and the corresponding ouster of the judiciary from the enter-

erations could, step by step, and as they succeed each other, unite all mankind in one family.

LIBERTY SAVED, supra note 6, at 5

241 LIBERTY SAVED, supra note 6, at 17.

242 2 CONNElley \& COUlter, supra note 33, at 636 (quoting ig THE PORT Folio 168 (1825)) (internal quotation marks omitted).

243 LiBERTY SAVED, supra note 6, at 23.

244 LAFAYETTE, supra note 37 , at 9.

245 Replevin Laws Resolution, supra note 120 , at 250. 
prise of constitutional construction. This argument was not one for shared departmental authority or for judicial deference or restraint; the people were absolutely supreme, and the judiciary was absolutely illegitimate. "Either good or bad, the control of a law is exclusively with the people in their general assemblies posterior to that in which it was enacted .... I It is never with the judges; it is always with the people to decide on ... the constitutionality or propriety of a law."246 According to the new-court platform, "[t]he sole judges of constitutions, are the people, by their delegates or representatives in legislative assemblies." 247 Given the new court's electoral failures in 1825 and 1826 , the complete ouster of the judiciary from the constitutional enterprise may have been too extreme for many voters. But the old-court party's strategy probably had much to do with the electoral reversal as well: it successfully moderated its rhetorical position on the locus of constitutional interpretation just as the new court's vision became more extreme.

2. The Old-Court Party's Moderate Judicial Constitutionalism. Kentucky supporters of judicial review responded with a robust defense of the constitution as a paramount, unalterable foundational law - but as the controversy developed, they acknowledged an important role for public constitutional judgment even while seeking reestablishment of judicial review. During the course of the debate, the oldcourt position stressed the supremacy of the document and the fixed nature of its commands. In the old-court conception, every government official acted with "a paramount law hanging over him when he sits in his official seat." ${ }^{248}$ George Robertson argued in his Plebian letters that "to be free, we must have a free constitution, and that constitution must be supreme." ${ }^{49}$ Rejecting the new-court rhetoric that suggested constitutional norms might adapt over time, judicial review partisans argued for the inviolability of constitutional principle. "[N]o one feature of the constitution can be changed, except by the whole people, in convention," argued the old-court party's "manifesto," reasoning that "the inviolability of our constitution is essential to the life, liberty, and property of every citizen." 250 Robertson wrote that "[t]he citizen should hold the constitution as the Christian does the decalogue, sacred and inviolable."251 This exaltation of the constitution compelled a vigilant attitude toward legislative innovation, even in harsh economic times. "Let no one think that any violation of his con-

\footnotetext{
246 LIBERTY SAVED, supra note 6, at I8.

247 Id. at I.

248 RESPONSE OF THE JUDGES, supra note I 2 I, at 30.

249 PLEBIAN, supra note I2, at I25.

250 MANIFESTO OF THE OLD COURT PARTY, supra note I82, at IOI.

251 PLEBIAN, supra note $\mathrm{I} 2$, at $\mathrm{I} 23$.
} 
stitution, under any circumstances, or for any purposes, is sufferable," wrote Robertson. ${ }^{252}$ "If one violation be tolerated, another is justified by the example; usage ripens into law; and the whole constitution is superseded; it becomes passive and exanimate."253

This intolerance to constitutional "violation," however, went handin-hand with a rhetoric that ultimately invited members of the public to become active participants in scrutinizing the validity of official action. This rhetoric was not the initial thrust of the old-court defense of judicial review, which originally offered a theory that judges were the primary, if not exclusive, arbiters of constitutional norms. In their opinion striking down the relief laws, the old-court judges rejected the legislature's populist constitutional judgment, stating that "it is not in the opinion of the legislature that the court is to search for the true meaning of the constitution." 254 Instead, the judges maintained, "it is incumbent on the court to pronounce the paramount authority of the constitutions," and to "decide for itself upon the constitution" based upon "its own reflections and deliberations." 255 In their address defending judicial review in December 1824 , the judges continued to deny the competence of the voting public to make intelligent judgments on constitutional matters, asking whether "the ideot [sic], the lunatic, the man whose intellect is destroyed by intemperance ... all of whom have a right to vote[, must] 'perceive at once' the propriety of [a constitutional] decision."256 This right seemed untenable to the judges, who instead proclaimed that "[t]o our minds the invalidity of the law must be obvious and palpable."257 This position was dubious politically in the majoritarian culture of Kentucky, and it was expressed in a particularly poor fashion. For the remainder of the debate, new-court literature constantly reminded the public that the judges thought of them as "idiots and lunatics." 258

Following the judges' unpopular formulation, a critical component of the old court's campaign to reestablish judicial review was an enhanced effort to persuade voters that they could play a meaningful role in the constitutional enterprise, even in a regime with strong-form judicial review. This effort was partially exemplified by general paeans to public virtue as a foundation for the constitutional regime. The power of the constitution, said Robertson, "is altogether moral," and its

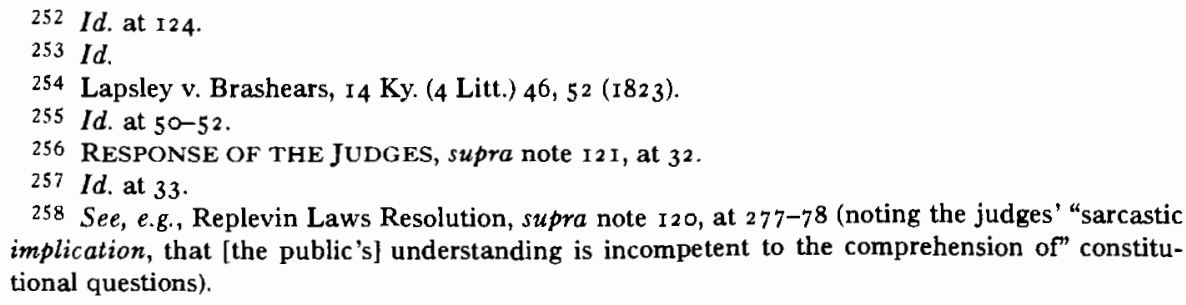


"efficiency consists in the public sentiment of its inviolability. The soul which animates it is the people's reverence. The cement which holds its parts together is the people's virtue and intelligence." 259 But the old court was more specific in inviting the public's constitutional judgment on certain matters. Its "manifesto" described as "fundamental" and "self-evident" the notion that since "free government [was] instituted by the people, and for their benefit, they are the final judges of all political questions, the only umpires who can adjust irreversably [sic], collisions of the departments, which endanger the equilibrium of the constitution." 260

Like any theory of constitutionalism that endorses both relatively strong judicial review and a degree of participation by the public (or the political branches), the old-court theory contained potentially destabilizing ambiguities. If both public and judicial interpretive judgments were important and legitimate, whose judgment would control in the event of disagreement? And if judicial constructions trumped contrary public opinion in actual cases, was the public's participation meaningful, or was it merely conceptual window dressing applicable only in times of constitutional consensus? George Robertson recognized the existence of these problems and proposed two very different conceptual solutions. Robertson's first solution was to bifurcate questions of supremacy into those involving "private right" and those raising "political questions." 261 In the former, "the judiciary is the only, and from necessity, the ultimate arbiter." 262 However, "[t]here may be constitutional questions which can be decided only by the people; and the only mode of deciding them is at the polls."263 A separationof-powers controversy involving a "collision between the... departments" was just such a question, and "[n]o judicial tribunal can decide such a controversy," because "it is not a judicial matter - it is political."264 Part of the rationale for disqualifying the legislature and the judiciary from ruling with finality in such a dispute rested on ordinary conflict-of-interest principles: placing the public in the position of an arbiter of separation-of-powers clashes avoided having the judiciary or

259 PLEBIAN, supra note $\mathrm{I} 2$, at I23.

260 MANif ESTO OF THE OLD COURT PARTY, supra note 182 , at 100

261 For an illuminating treatment of the origins and development of the political question doctrine, see Rachel E. Barkow, More Supreme Than Court? The Fall of the Political Question Doctrine and the Rise of Judicial Supremacy, I02 COLUM. L. REV. 237, 248-58 (2002).

262 PLEBIAN, supra note 12 , at 124 . Even in distinguishing between private suits and political questions, Robertson suggested that the public's judgment might ultimately control the former, but through a more attenuated process. He wrote that in cases of private right, judges are supreme in the context of the case, but "public sentiment may, whilst it cannot reverse the decision, reverse the principle." Id.

263 Id.

264 Id. 
the legislature "decide its own cause - adjudicate on its own acts."265 In any event, when such a question arose, the old-court party was clear about the proper locus for its resolution: "The people who made the constitution, and for whom it was made, are the only umpires," with a "right to settle the construction of their constitution (in the only way in which they can do it, by voting at the polls)."266

This concession of popular supremacy on certain important constitutional matters probably helped ameliorate public concern about the countermajoritarian implications of reestablishing judicial review in Kentucky, and it likely contrasted favorably with the new-court party's more exclusive formulation of its position. Another old-court party concession, which qualified the absolute independence life-tenured judges otherwise enjoyed, may also have been instrumental: Although they described judicial independence as "the most important feature" ${ }^{267}$ of the constitution, the old-court advocates noted that "[b]y an independent judiciary, we mean a judiciary independent of the will of less than two-thirds of the legislature."268 Yet despite defending judicial independence adamantly, the same document used the phrase "the qualified independence of the judiciary." 269 In the context of the Kentucky polity, which permitted supermajority removal of judges by "address" on any ground not sufficient for impeachment, these are surprising concessions, suggesting an endorsement of the original newcourt idea that judges could be removed by the requisite two-thirds supermajority for mere good-faith error of opinion. This concession by defenders of judicial review, like their endorsement of occasional public constitutionalism on political questions, probably contributed to their success in the 1825 and 1826 elections. Conversely, the new-court doctrine of absolute majoritarian constitutionalism, with no room for judicial authority, may have struck a majority of Kentucky voters even those who favored removing these three particular old-court judges - as too extreme.

\section{RAMIFICATIONS ACROSS GEOGRAPHY, TIME, AND THEORY}

Without a total revolution, there can be no such political solecism in Kentucky, as a "de facto" court of appeals. There can be no such court, whilst the constitution has life and power. There has been none such. ${ }^{270}$

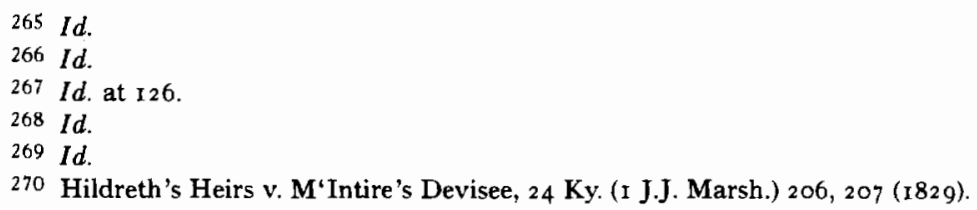


In I829, with the old court of appeals and the principle of judicial review reestablished in Kentucky, there arose the minor housekeeping matter of what to do about the fifty-two decisions issued by the newcourt judges in 1825 . Would the opinions of this now-repudiated court be binding precedent, or would they be disregarded as the symptoms of a momentary constitutional blemish? The old court chose the latter course, declaring that the new court had operated without constitutional authority and that its actions were therefore null and void.271 George Robertson, the former leader of the old-court political retrenchment, was now a judge on the court of appeals and must have relished drafting the definitive repudiation of his former adversaries' actions. Robertson wrote that "[t]here can be no such court" as the new court "whilst the constitution has life and power. There has been none such." 272 The new-court jurists "were not judges," and thus "had no power; all their acts, as well as those of the pretended clerk, were null and void."273

This repudiation prompts the question whether the entire episode is properly regarded as essentially overwritten, or nullified, by the victorious paradigm of judicial review. What became of the rhetoric of popular will and judicial illegitimacy that temporarily persuaded a majority of the state's citizens? The history of American constitutionalism has been one of more entrenched judicial review, and the legislative supremacy of the new-court party became, to use its own terms, a "divergent tendency" set apart from this "general stream." 274 The ideal of monistic popular governance it described - and briefly actuated in 1824 and I 825 - differs fundamentally not just from modern conceptions of the judicial review power, but also from the view predominant even in the early nineteenth century.

Still, the Kentucky episode yields important historical and theoretical lessons, which can be grouped into three general categories. First, because the Kentucky crisis produced an unusually focused debate on judicial review, and attracted national attention and commentary, it offers descriptive lessons about the contemporaneous importance (or unimportance) of Marbury in resolving such a debate, and about the positions of several key national leaders on this concrete judicial review question. A second group of historical conclusions traces the influence of the controversy on several immediately subsequent legal and political developments, most distinctly the composition and rhetoric of the Jackson administration, state and federal judicial behavior, and state constitutionalism. Finally, the rhetoric and resolution of the Kentucky

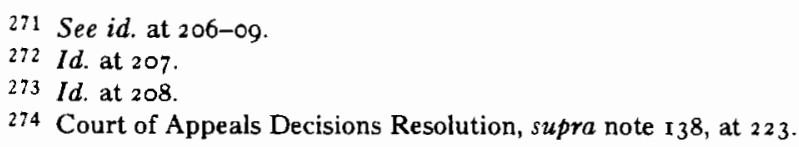


crisis sheds light on the questions posed by recent scholarship on the early development of judicial review in the United States.

\section{A. Insights Regarding Marbury's Influence and the Opinions of National Leaders}

As explained above, national politics in the early nineteenth century never generated a sustained debate over horizontal judicial review that was uncluttered by disagreements over federalism and executive authority. 275 Because the basic judicial review question was so squarely presented in Kentucky, the episode illuminates two related historical questions: the importance (or unimportance) of the Marbury precedent in a focused public debate over its major proposition, and the opinions of national leaders on the judicial review power as revealed by their specific comments on the Kentucky crisis. There is, of course, an even broader set of questions about early American attitudes on horizontal judicial review that the Kentucky debate informs; these are assessed in a later section.

I. "Marberry and Madison ... [an] unhappy citation[]." 276 - The Kentucky debate centered on the judiciary's authority to review coordinate statutes for their constitutionality - a question central to Chief Justice Marshall's opinion in Marbury twenty years earlier. That opinion today is almost obligatory - and often independently sufficient support for any assertive exercise of judicial review authority. ${ }^{277}$ Yet in a three-year public debate during which the judiciary's review authority was up for grabs, the old-court supporters mentioned Marbury rarely, and even then to little persuasive effect. The sparse rhetorical use of that case, and the opposition's dismissive response when it was invoked, says much about Marbury's relative unimportance in the early nineteenth century and confirms recent scholarly accounts that deemphasize its impact. ${ }^{278}$

For example, in its 1823 Lapsley opinion, just before declaring the replevin laws void, the Kentucky Court of Appeals expressly justified its review power, professing a "deep sense of ... duty" to pass on statutes' constitutionality. ${ }^{279}$ It declared that "it is incumbent on the court to pronounce the paramount authority of the constitutions," and tc

275 See supra pp. $83 \mathrm{I}-32$.

276 Replevin Laws Resolution, supra note 120 , at 247.

277 See, e.g., United States v. Morrison, 529 U.S. 598, 607, 616 \& n.7 (2000); City of Boerne v Flores, 52 I U.S. 507, 5 I6, 536 (1997); Clinton v. Jones, 520 U.S. 68I, 703 (1997); United States v Lopez, 5 I 4 U.S. 549, 566 (I 995) (noting that Marbury established the doctrine of judicial review).

278 This scholarship is explored below in section III.C.I, pp. 888-92. Although the Kentucky controversy confirms Marbury's unimportance at the time, it complicates these claims in that thi reason they offer for that case's unimportance is that judicial review was already generally ac. cepted when the opinion was issued.

279 Lapsley v. Brashears, I4 Ky. (4 Litt.) 4 I, 52 (1823). 
[Vol. I I $7: 826$

"decide for itself upon the constitution" based upon "its own reflections and deliberations."280 Given the distinctly Marshallian character of these pronouncements, the court might have cited Marbury for support, but it did so nowhere in its opinion. Likewise, when facing removal from office by address in December I824, the three judges offered a lengthy and well-argued defense of their authority to pass on the constitutionality of statutes - but in nearly forty pages of argument, they mentioned Marbury only once, as part of a string citation of more than a dozen cases. ${ }^{281}$ Similarly, judicial review supporters' lengthy appeals to the public in the ensuing campaigns made scant reference to the case.

What explains Marbury's irrelevance in the eyes of the Kentucky judicial review supporters? One basic factor relates to conceptions of judicial precedent that both sides in the Kentucky debate (and most people in early America) shared. Neither side thought that courts could legitimately create new legal norms in their rulings; rather, their role was only to discern and apply preexisting principles to the cases before them. Old-court supporters maintained that this role was possible (and desirable) with respect to constitutional principles, while new-court advocates were skeptical that judges could dispassionately do so in the realm of constitutional interpretation. ${ }^{282}$ Both sides agreed, however, that precedent played little or no role in establishing or creating constitutional principles. Explaining its lack of reliance on case law, the old court stated that it "might advert to the various adjudications of the supreme court of the United States" on the question of judicial review, but because "the constitution itself contains a declaration of its own supremacy,... whatever is declared by the constitution, can derive no additional force by being repeated by the judiciary." 283 And the new-court legislature agreed, stating that "cases do not alter principle. They may illustrate or violate principle; they cannot alter it."284 In this framework, the volume of case law supporting a principle was more important than its prominence, because the former at least offered indirect support for the idea that the principle was widely accepted in society. Marbury, a single case, was insufficient to "establish" any principle, despite its authoritative tone and despite (or perhaps because of) the renown of its author. Arguing to a populace that did not take judicial review for granted, and that disputed the authority of constitutional precedent, the judicial review

\footnotetext{
280 Id.

281 See RESPONSE OF THE JUDGES, supra note I $2 \mathrm{I}$, at I 2.

282 See supra section II.B, pp. 869-77.

283 Lapsley, 4 Ky. (4 Litt.) at 51 .

284 Replevin Laws Resolution, supra note I 20, at 247.
} 
supporters needed substantive reasons beyond stare decisis to win popular support.

Two other factors that diminished Marbury's persuasive force in the Kentucky contest can be seen in the new-court response to a rare mention of the case. First, the legislature denounced "Marberry [sic] and Madison" as an "unhappy citation[]," by virtue of which "the President of the United States was made to succumb, for party purposes, to the [Supreme Court]."285 As this short statement reveals, Marbury was regarded as primarily a judicial assertion of power over the executive, not an important judicial review decision. Second, the opinion was fundamentally political and corrupted by party purposes, and so was particularly unpersuasive in a state whose electorate was mostly composed of "rather bigoted republican[s]." 286 Throughout the judicial review struggle, new-court advocates attempted to portray judicial review supporters as staunch backers of the Federalist agenda. Invoking Marshall or Hamilton would have entailed significant political costs. ${ }^{287}$

2. The Views of National Leaders. - We know with particularity what many Kentuckians said about the judicial review power in a controversy in which the question was squarely presented, and as noted above, we can discern the relative unimportance of Marbury in that debate. The comments of national political figures on the Kentucky crisis yield similar insights. Although a question of state constitutionalism, the crisis was nationally publicized and attracted commentary from even the most prominent Americans.

Predictably, Chief Justice Marshall strongly supported the judicial review party in Kentucky, and he seemed to suggest that other members of the Supreme Court did as well. After the old-court party prevailed in the elections of 1825 , he wrote to his cousin Martin that "[w]e have been very much engaged with your political contests in Kentucky \& have rejoiced a good deal at the triumph of what we be-

$285 I d$.

286 Elias PyM Fordham, PERSonal NarRative of Travels in Virginia, MaryLAND, Pennsylvania, OHIO, Indiana, Kentucky; AND OF a Residence IN THE ILLINOIS TERRITORY: I8I7-I8I8, at I80 (Frederic Austin Ogg ed., I9o6). Fordham also noted that "[i]t is said by enemies, that were a person to travel through Kentucky and openly approve of Monarchical principles, he would be stabbed. This is not true; but it is true that they are irascible, to a great degree ...." Id. He advised that "it would not be wise for any man to preach up even federal, that is, tory, principles in this State." Id.

287 One judicial review supporter was pilloried because he once "actually rose in his place and proposed to give the name of Hamilton to a new county which was about to be established!" BANK DINNER, supra note 39, at 34. An interesting aspect of Marbury's history is its very gradual depoliticization. Its iconic stature was possible only after almost a century had rendered the political fractures of the time historical relics. For an account of how Marbury was reanimated late in the nineteenth century, see Davison M. Douglas, The Rhetorical Uses of Marbury v. Madison: The Emergence of a "Great Case", 38 WAKE FOREST L. REV. 375, 386-407 (2003). 
lieve to be sound constitutional principles at your late elections."288 John Quincy Adams took a similar position, writing early in the controversy that Henry Clay, a supporter of the old court, was on "the side of justice."289

James Madison's view on the Kentucky dispute is more interesting. Most scholars agree that Madison came to support judicial review generally. While there is disagreement about how early he came to that view and what sort of judicial authority he supported, ${ }^{290}$ Madison's position on the Kentucky question is clearer. In retirement on his Virginia estate in 1825 , Madison received what he described as a correspondent's "sad picture of the condition of Kentucky," and he wrote in reply that "no doctrine can be sound that releases a Legislature from the controul of a Constitution." 291 He believed that "[i]f there be any ... of the Republican faith who have been surprised into such an error, time and reflection cannot fail to rescue them from it."292 In the context of the Kentucky dispute, Madison's choice of words is noteworthy. The new-court critics of judicial review adamantly denied that they were "releas[ing]" the legislature "from the controul of a Constitution"; for them, this control was exercised by the public in its annual elections, not by the courts. ${ }^{293}$ For Madison to opine that a system of annual statewide elections (without judicial review) "releases a Legislature" from constitutional control was to say that, in his view, popular constitutional oversight was at best scant control.

Three other Presidents expressed more qualified views on the Kentucky situation. Abraham Lincoln favored the judicial review supporters, albeit fifteen years after the fact and in a joint Illinois legislative document. Lincoln signed (and may have drafted) a minority protest to a state judicial reorganization, invoking the Kentucky crisis as an example of "the fearful consequences of ... interference with the

\footnotetext{
288 Letter from John Marshall to Martin P. Marshall (Dec. 27, 1825), in 10 THE PAPERS OF John MARSHALl 260, 26I (Charles F. Hobson ed., 2000). The "we" in the statement is interesting, and may have referred to other Justices of the Supreme Court, who at the time lived together in Washington boardinghouses. Charles Warren, The Story-Marshall Correspondence (1819183I), 2 I WM. \& MARY Q. HIST. MAG. I, 22 (I94I).

2896 MEMOIRS OF JOHN QUINCy ADAMS 57 (Charles Francis Adams ed., Philadelphia, J.B. Lippincott \& Co. 1875).

290 Compare, e.g., Farber, supra note 22, at 423 (dating Madison's support of judicial review to the introduction of the Bill of Rights), with Kramer, supra note 5, at 90-93 (citing a letter written by an older Madison in 1834 supporting judicial review).

291 Letter from James Madison to George Thomson (June 30, 1825), in 3 LETTERS AND Other Writings of JAmes Madison 490, 49I (Philadelphia, J.B. Lippincott \& Co. 1865) [hereinafter Madison Letter].

292 Id.

293 See supra section II.A, pp. 857-69; see also Replevin Laws Resolution, supra note $\mathrm{r} 20$, at 250 ("The people take their representatives to account annually, and test the fidelity of their agency....").
} 
courts by the Legislative authority." 294 Then-Governor of Tennessee Andrew Jackson is said to have stated more pragmatically at the height of the crisis that "forty thousand muskets would be required to rectify the politics of Kentucky."295 Jackson would later bring two of the leading new-court rhetoricians, Francis Blair and Amos Kendall, to Washington as part of his "Kitchen Cabinet," 296 after recognizing their successful mobilization of popular opinion in Kentucky against entrenched economic and political interests.

But the man whose opinion mattered most to both sides of the Kentucky debate (and to whom both made express appeals for support) refused to support either position. In response to a missive from an old-court supporter in early I 825 , Thomas Jefferson wrote:

You wish me to give an opinion on the question which at present agonises Kentucky. [N]o, my dear Sir, at the age of $82 \mathrm{I}$ have no inclination to volunteer myself into a question which convulses a nation. [Q]uiet is my wish, with the peace and good will of the world. [W]ith it's [sic] contentions I have nothing to do. ${ }^{297}$

Jefferson's is a tantalizing refusal, and perhaps, if one does not take his protestations of weariness at face value, one can speculate that there were other reasons why he chose not to get involved. Jefferson may have recognized that by choosing sides in the Kentucky dispute, he would necessarily have alienated significant numbers of his supporters. If forced to pick sides, however, Jefferson likely would have favored retention of some type of judicial review authority over the total ouster proposed by the new-court advocates. In an 1820 letter to William Jarvis of Massachusetts, Jefferson argued for coordinate interpretive authority to be exercised by all three branches — consistent with his departmentalist philosophy - and conceded some such authority, albeit narrow, for courts because "judges certainly have more frequent occasion to act on constitutional questions" in the course of hearing cases. ${ }^{298}$ Although John Marshall and Joseph Story read Jefferson to be proposing a total ouster of the judiciary from the enterprise of con-

\footnotetext{
294 Joseph Gillespie et al., Whig Protest in Illinois Legislature Against the Reorganization of the Judiciary (Feb. 26, I84 I), in I THE COLleCTED WORKS OF ABRAHAM LiNCOLN 244, 248 (Roy P. Basler ed., I953).

295 Letter from Robert P. Henry et al. to Andrew Jackson, reprinted in 28 NILES' W KLY. REG. 5 I (Mar. 26, I825).

296 See ARTHUR M. SCHLESINGER, JR., THE AGE OF JACKSON 67-73 (1945) (describing Jackson's reliance on a small group of "confidential counsel," such as Kendall and Blair, rather than on his formal cabinet).

297 Letter from Thomas Jefferson to George Thomson, supra note + , at 295 , quoted in 2 CONNELLEY \& COULTER, supra note 33 , at 633 .

298 Letter from Thomas Jefferson to William Charles Jarvis (Sept. 28, I820), in 12 THE WORKS OF THOMAS JefFERSON I6I, I63 (Paul Leicester Ford ed., I 905).
} 
stitutional interpretation, ${ }^{299}$ Charles Warren concludes otherwise, ${ }^{300}$ stating that "Jefferson did not deny the power of the Court to pass upon the validity of [legislative] action in a case involving the rights of individuals." ${ }^{301}$ The decision that touched off the Kentucky crisis was just such a case, involving the private rights of an individual debtor and an individual creditor. If Warren's reading is correct, then Jefferson might have taken the old-court position just as Madison did. Doing so would have greatly disappointed the new-court populists who frequently invoked his name, and it is understandable that Jefferson, late in life, would have been reluctant thus to alienate large groups of supporters in Kentucky and elsewhere. That Madison asked the Kentucky old-court recipient of his own unambiguous letter to keep it confidential - he was not "willing to be brought before the public" 302 on this issue - indicates that he, too, had some qualms about openly siding with the Chief Justice and other strong supporters of judicial review.

\section{B. Influences on Judicial Behavior and Andrew Jackson's Constitutionalism}

The Kentucky controversy influenced subsequent legal and political events in two ways in the years immediately following the crisis. First, although the principle of judicial review survived the Kentucky episode, Kentucky Court of Appeals judges, and perhaps even their national counterparts, moderated their exercise of the practice in at least a few important cases to take account of popular opinion. Second, two of the new-court party's leading rhetoricians became important members of the Jackson administration and used the same populist rhetorical techniques they had practiced in Kentucky to propagate Jackson's constitutional vision.

I. Judicial Behavior. - Modern scholarship commonly recognizes that even unelected judges respond to popular opinion in their decisionmaking. ${ }^{303}$ With respect to various eras in U.S. history, there is evidence that courts rarely are consistently countermajoritarian, but instead often moderate their decisions to comport reasonably well with

299 See Warren, supra note 288 , at 7 (quoting a letter to Marshall in which Story interpreted Jefferson as "in the most direct terms den[ying] the right of Judges to decide constitutional questions").

300 Id. at $8-1 \mathrm{I}$.

301 Id. at 9.

302 Madison Letter, supra note $29 \mathrm{I}$, at $49 \mathrm{I}$.

303 See, e.g., Robert G. MCCloskey, The AMERICAN Supreme COURT 223-24 (1960); Robert A. Dahl, Decision-Making in a Democracy: The Supreme Court as a National PolicyMaker, 6 J. PUB. L. 279 (1957); Barry Friedman, Dialogue and Judicial Review, 91 MICH. L. REV. 577, 590-609 (1993); Mark A. Graber, The Nonmajoritarian Difficulty: Legislative Deference to the Judiciary, 7 STUD. AM. POL. DEV. 35, 70-72 (1993). 
public opinion. In keeping with this conception of judicial behavior, there is strong evidence in the Kentucky episode of the old-court judges' shaping their exercise of judicial review in ways that correlated with popular opinion. It appears that the U.S. Supreme Court, too, was influenced by the strong public reaction in Kentucky.

The Kentucky old-court reaction commenced even as that court sat in temporary constitutional exile during the schism of 1825 . The initial vehicle for regaining public approval was the court's treatment of Green v. Biddle, the highly unpopular Marshall Court decision that invalidated the state's occupying claimant laws. ${ }^{304}$ In an opinion handed down while the heated political campaign was still active, the old-court judges maintained that Green was not binding on them. ${ }^{305}$ The court stated that although it would "consider [itself] bound by the decisions of the Supreme [C]ourt of the United States settling a construction of the constitution," it did not regard Green as settling anything because it was the opinion of less than a majority of the Court. ${ }^{306}$ In several decisions in the years immediately following Green, the old court, even when solidly reestablished, continued to deny the force of Green with respect to the state's occupying claimant laws. The Kentucky court's disregard of Green is not entirely surprising, given state courts' general treatment of Marshall Court precedents in this era. What is unusual, though, is that it acknowledged the Court's controlling authority in principle, refusing to apply Green only because of the technical matter of its garnering too few votes.

Still more interesting, and almost certainly reflecting an awareness of the outrage Green had triggered, is the Supreme Court's repudiation of Green less than a decade after its issuance. In Hawkins v. Barney's Lessee ${ }^{307}$ decided in $183 \mathrm{I}$, the Court held that the Virginia Compact was not a "contract" that disabled Kentucky from altering its land laws. In language that would have been at home in a Kentucky newcourt tract from the I820s, Justice Johnson explained that "[i]t can scarcely be supposed that Kentucky would have consented to accept a limited and crippled sovereignty... [or that Virginia] would have wished to reduce Kentucky to a state of vassalage." ${ }^{308}$

\footnotetext{
304 See supra pp. 843-44 (discussing Green v. Biddle, 2 I U.S. (8 Wheat.) I (1823), and the Kentucky reaction).

305 See Bodley v. Gaither, I9 Ky. (3 T.B. Mon.) 57 (1825). Only three of the seven Justices joined the $\mathrm{I}_{823}$ Green decision, and only four in total participated. Justice Washington was joined by Justices Duvall and Story, while Justice Johnson dissented. Justices Todd and Brockhurst were incapacitated by illness and Chief Justice Marshall recused bimself, apparently because of his family's significant land interests in Kentucky. See JEssup, supra note 33, at 213-3 I (providing a detailed discussion of Green and Kentucky's reaction).

306 Bodley, I9 Ky. (3 T.B. Mon.) at 58 .

307 3o U.S. (5 Pet.) 457 ( $183 \mathrm{r})$.

308 Id. at $466-67$.
} 
In Hawkins, the Supreme Court reversed the substance of the unpopular Green decision; a few years later, it rectified what Kentuckians thought was Green's grave procedural flaw - the invalidation of a state law by a decision joined by less than a majority of the Court. On two occasions in 1834 and 1835 , Chief Justice Marshall announced a policy that the Court's constitutional decisions must be supported by a majority of the Justices. ${ }^{309}$ The Court's reversal of both the substance and the procedure of the decision that had enraged Kentuckians suggests that the intensity of the public reaction in that state affected the Court's subsequent decisionmaking.

2. Jackson's Constitutionalism. - The link between the Kentucky episode and the Jacksonian ascendancy in American politics was even more direct. Jackson was aware of the populist rhetoric of the newcourt advocates in Kentucky, and he hired two of the leading newcourt propagandists to join his "Kitchen Cabinet" and assist in framing his administration's rhetoric of democratic constitutionalism. Amos Kendall, an important journalist in the new-court campaign in Kentucky, came to Washington as an adviser and speechwriter for Jackson, later becoming his postmaster general. ${ }^{310}$ Jackson invited Francis Blair, a new-court attorney and political operative, to Washington to take charge of the Washington Globe newspaper, a key platform for the administration's views. ${ }^{311}$ In addition to his prominent role in authoring new-court pamphlets in the Kentucky crisis, when Blair was the clerk of the new court he had infamously carried out the late-night break-in to carry off the old court's physical records. ${ }^{312}$ Once in Washington, Kendall and Blair became important members of Jackson's cadre of advisers; of all his advisers, they "shared the greatest influence" on the President. ${ }^{313}$ Contemporaries were aware of the influence of these Kentuckians and were often critical of it. One member of Congress referred to Kendall as "the President's thinking machine, and his writing machine - ay, and his lying machine! . . [N]othing was well done without the aid of his diabolical genius." 314

\footnotetext{
309 See Briscoe v. Commonwealth Bank of Ky., 33 U.S. (8 Pet.) I I 8 , I 2 I (I 834 ) ("The practice of this court is, not ... to deliver any judgment in cases where constitutional questions are involved, unless four judges concur in opinion, thus making the decision that of a majority of the whole court."); see also New York v. Miln, 34 U.S. ( 9 Pet.) 85 ( 1835 ) (refusing to hear argument on constitutional questions because a "full court" was not sitting at the time).

310 See SCHLESINGER, supra note 296 , at $67-70$.

311 See id. at $70-72$.

312 See STICKLES, supra note 33 , at 69 .

313 Richard B. Latner, The Kitchen Cabinet and Andrew Jackson's Advisory System, 65 J. AM. HIST. 367, 380-8I (1978); see also SCHLESINGER, supra note 296, at 67-73 (describing Blair and Kendall as " $\mathrm{t}] \mathrm{h}$ t two leading members of the Kitchen Cabinet").

314 CONG. GlOBE, 25th Cong., 3d Sess. app. 387 (r838) (statement of Rep. Wise), quoted in SCHLESINGER, supra note 296, at 73 ; see also Io MEMOIRS OF JOHN QUINCY ADAMS 366 (Charles Francis Adams ed., Philadelphia, J.B. Lippincott \& Co. 1876), quoted in SCHLESINGER,
} 
Despite the significant roles that Kendall and Blair played, it would be too much to say that Jackson's constitutionalism was primarily derivative of the Kentucky new-court platform in any causal sense. Jackson came to Washington with his own substantive vision, and on the central issue of the Kentucky court crisis - the right of courts to engage in judicial review - his view differed from those of Blair and Kendall. Although leery of too much judicial authority and protective of the executive's coordinate interpretive domain, Jackson did not share the new-court endorsement of a complete ouster of the judiciary from constitutional matters. Yet the new-court rhetoric that Blair and Kendall had framed in Kentucky was rich with ideas - distrust of centralized authority and elite institutions, emphasis on majoritarian decisionmaking, and economic egalitarianism - that correlated with Jackson's preexisting philosophy and that were conceptually and rhetorically useful in furthering his political agenda. These ideas were regular themes in Blair's anti-bank editorials in the Globe and informed the 1832 Bank Veto Message (considered the most notable written statement of Jackson's constitutionalism) which was written primarily by Kendall. ${ }^{315}$ Kendall drew on his Kentucky rhetoric in preparing arguments against rechartering the Bank of the United States: he collected a complete set of his Kentucky newspapers, on the theory that the issue of bank privilege "must come before the nation, and a recurrence to these papers will save me much thought." 316 What "these papers" contained was as important in style as it was in substance, for Kendall and Blair had learned in Kentucky the technique of mobilizing public sentiment through widely circulated written rhetoric. In their substantive distrust of elite institutions, and in their experience with this new democratic political technique, Kendall and Blair were like-minded and highly useful supporters of Jackson's presidency who could articulate his vision effectively. According to historian Arthur Schlesinger, this "supreme skill in interpreting, verbalizing and documenting Jackson's intuitions" for popular consumption was the critical asset Kendall brought to the Jackson presidency, and it was a skill forged in significant part in the Kentucky debates. ${ }^{317}$

\footnotetext{
supra note 296, at 73 (explaining that Jackson and later Van Buren "[b]oth ... [had] been for twelve years the tool of Amos Kendall, the ruling mind of their dominion" (omission in original)).

315 See Lynn L. Marshall, The Authorship of Jackson's Bank Veto Message, 50 MISS. VALLEY HIST. REV. ${ }^{66-73}\left(\mathrm{I}_{96}\right)$ (analyzing original drafts of the message to conclude that Kendall, not Roger Taney, was its author).

316 Id. at 473 (quoting Letter from Amos Kendall to Francis P. Blair (Nov. 22, 1829)) (internai quotation marks omitted).

317 SCHLESINGER, supra note 296 , at 70 .
} 


\section{Broader Historical and Theoretical Lessons}

It is possible, with some caution, to extend the analysis of the Kentucky episode further and thus illuminate recent broader scholarly accounts of judicial review and its place in American constitutional history. As with any case study, there are dangers in overgeneralization but corresponding benefits in the unusually concrete and detailed presentation of the issue. Because the basic question of judicial review was squarely presented in Kentucky through the course of several political campaigns, the surviving literature is both voluminous and highly focused on that question. By shifting attention away from the national political discourse on judicial review - a discourse generated by a relatively small number of legal and political elites and often confounded by other issues, such as federalism - this episode of state constitutionalism provides insights that both confirm and complicate the analysis offered in broader accounts of judicial review during this era.

As to the question of early-nineteenth-century public attitudes toward judicial review, the Kentucky evidence can be read in several different ways. On one hand, the vitriolic and widespread opposition to judicial review that surfaced in the state seems to undermine claims of a developing American consensus on the topic. On the other, the voters' subsequent endorsement of the judicial review party by large margins, in campaigns where the issue was squarely presented and in a polity predisposed to majoritarian governance, suggests that the oldcourt rationales for judicial review persuaded even many skeptical citizens. A different analytical viewpoint is less equivocal and supports recent scholarly claims: to the extent that Kentuckians ultimately endorsed judicial review, it was judicial review of a more modest scope (in terms of its exclusivity and its methodology) than judicial power under the current doctrine. Finally, one historical irony of the Kentucky episode is that the decision to reestablish judicial review was itself an exercise of popular constitutionalism played out in an overtly majoritarian political space. A single issue dominated popular discussion in rare fashion, and the statewide votes were "triggering elections" with a clarity rarely, if ever, seen in national elections and those of other states. Each of the foregoing points is explored in more detail below, following a brief summary of some recent literature on these topics.

I. Recent Scholarship Assessing Conceptions of Judicial Review in the Early Republic. - American constitutional law scholarship is presently in the midst of a turn to history so pronounced that the trend 
itself has become a burgeoning field of academic discourse. ${ }^{318}$ One important strand of this historical turn is a growing body of work that explores early American conceptions of judicial review and reexamines the meaning and impact of the case that - in the more conventional academic and judicial account - was vital to establishing the doctrine. ${ }^{319}$ This newer work responds not only to the traditional academic emphasis on Marbury's importance, but also to the Rehnquist Court's frequent invocation of the traditional characterization of the case - with the implicit correlative that strong-form judicial review has been established and accepted in the United States for two centuries - in support of its controversial assertions of judicial authority. ${ }^{320}$ Accordingly, recent historical scholarship in this area has explored two basic questions, the first a narrow one about Marbury's impact and scope, and the second a more general one about early American understandings of the scope and legitimacy of the judicial review power.

Among scholars who have recently assessed the contemporaneous impact of Marbury $v$. Madison, the clear trend has been to deemphasize its influence on early American attitudes toward judicial review. By 1803 (and probably well before), the story goes, the practice of judicial review had become so unexceptional in the United States that the Marbury decision was unsurprising and relatively unimportant it enunciated no new rule. As Michael Klarman puts it, "[b]y I 803, the power of judicial review was sufficiently well settled that even Mar-

\footnotetext{
318 See generally LaURa Kalman, THE STRANGe CAREer OF LEGAL LIBERALISM I32-63 (1996); Martin S. Flaherty, History "Lite" in Modern American Constitutionalism, 95 COLUM. L. REV. 523, 5 29-49 (I995); Larry Kramer, Fidelity to History - And Through It, 65 FORDHAM L. REV. I627, 1629-30 (1997); Jack Rakove, Two Foxes in the Forest of History, I I YALE J.L. \& HUMAN. I9I, I92-93 (I999); G. Edward White, The Arrival of History in Constitutional Scholarship, 88 VA. L. REV. 485 (2002).

319 For examples of the traditional conception of Marbury as a landmark decision, see BICKEL supra note 16 , at $I$, which claims that "[i]f any social process can be said to have been 'done' at a given time and by a given act, it is Marshall's achievement" in Marbury with respect to judicial review; and David P. Currie, The Constitution in the Supreme Court: The Powers of the Federal Courts, I80I-I835, 49 U. CHI. L. REV. 646, 646, 65I (I982), which characterizes Marbury as an "explosive" decision that "establish[ed] the power of judicial review." Most leading constitutional law casebooks feature Marbury front and center in their first lessons on the American constitutional tradition. See, e.g., JESSE H. CHOPER ET AL., CONSTITUTIONAL RIGHTS AND Liberties I (gth ed. 200I); KathleEN M. Sullivan \& GERALD GuNTher, ConstituTrONAL LAW 3 (I4th ed. 2001). For an interesting rejoinder to the primacy Marbury enjoys in the law school curriculum, see Sanford Levinson, Why I Do Not Teach Marbury (Except to Eastern Europeans) and Why You Shouldn't Either, 38 WAKE FOREST L. REV. 553, 554-74 (2003), which explains "why Marbury should lose its pride of place in the current conception of how to teach ... American constitutional law."

320 One need not search long to find such uses of Marbury in Rehnquist Court decisions. See, e.g., cases cited supra note 277
} 
shall's critics had no gripe with him for exercising it."321 Larry Kramer agrees, stating that "Marbury broke no new ground in the theory or practice of judicial review." 322 Not only was Marbury relatively unimportant at first, but its ascendance in the American constitutional law canon came much later - almost a century after it was handed down - and then only after its meaning was recast in "mythic" form and put to argumentative use by both critics and supporters of a robust judicial bulwark against progressive legislation. ${ }^{323}$ The Kentucky episode helps confirm Marbury's relative unimportance in the early nineteenth century, even in the context of a vigorous concrete debate where such a precedent might have been useful (though for reasons having nothing to do with any broad consensus on the legitimacy of judicial review). ${ }^{324}$

As to the broader inquiry into early American conceptions of judicial review, recent accounts diverge in various ways; nevertheless, it is possible to discern two rough propositions upon which most scholars agree. The first is that the judicial review power that John Marshall exercised in Marbury, and that other judges practiced in other cases at the time, was more modest than that exercised by the modern Supreme Court, a fact that helps explain the general acceptance of the decision. There is disagreement about exactly how it was more modest. Larry Kramer, Barry Friedman, and Sylvia Snowiss have each described how the early Marshall Court's judicial review power was less exclusive or "supreme" than the current Court's, leaving at least some meaningful interpretive authority vested in the elected branches of government or in the people themselves. ${ }^{325}$ Robert Clinton pushes this

\footnotetext{
321 Klarman, supra note 20, at I II7. At most, writes Klarman, "Marbury eliminated the few remaining doubts as to whether courts had the power to invalidate federal legislation under the federal constitution." Id.

322 Kramer, supra note 5, at 88; see also CLINTON, supra note 10, at 102-03 (ascribing the lack of a significant reaction to Marbury to the decision's consistency with prevailing norms); NELSON, supra note Io, at 73 ("[T]he doctrine of judicial review, which Marbury proclaimed, was not novel.").

323 See Clinton, supra note ro, at $176-91$; Davison M. Douglas, The Rhetorical Uses of Marbury v. Madison: The Emergence of a "Great Case", 38 WAKE FOREST L. REV. 375, 386-407 (2003).

324 See supra section II.A, pp. 857-69.

325 See SYlvia SNOWISS, JUdicial Review AND THE LAW OF THE ConStitution i-89 (I990); Friedman, supra note 5, at 375-8I; Kramer, supra note 5, at 12-13. Both Kramer and Snowiss offer comprehensive accounts of why early American conceptions of constitutionalism compelled the conclusion that significant - even primary - interpretive authority remained outside the courts. Both explore, in different ways, the manner in which the Constitution was regarded as fundamental law subject to popular control, as opposed to the ordinary law that was the everyday fodder of judges and lawyers. See SNowiss, supra, at 6 (stating that during the Marshall Court era, constitutional interpretation, unlike ordinary law, was "selfevidently ... reserved for political and popular, not judicial, resolution"); Kramer, supra note 5, at Io, 16-74. Friedman also describes early American beliefs that judicial interpretive authority
} 
claim further, contending that early judicial authority was tightly restricted to "the confines of the particular case before it" 326 and categorically limited to review of only those statutes that bore "directly upon the performance of judicial functions." 327 William Nelson emphasizes a law-politics distinction, arguing that early-nineteenthcentury courts confined their review to the application of "fixed principles" 328 of law while leaving exercises of "political discretion" 329 to other branches of government. ${ }^{330}$ All of these scholars, however, regard the judicial review power that Chief Justice Marshall exercised in Marbury, and that other courts exercised contemporaneously, as less extensive than the modern doctrine. ${ }^{331}$ As Nelson puts it, "Marshall did not understand judicial review as we do today." 332

A second ground of scholarly consensus follows directly from the foregoing analysis: once the doctrine of judicial review was thus limited in theory and practice, it was accepted by most Americans of the time. The lack of overt national or state-level debate about the basic horizontal judicial review power supports this claim. Surveying this general silence, William Nelson is able to say that "[j]udicial review was ... uncontroversial during the early nineteenth century," even at the state level, ${ }^{333}$ and that "[e]veryone agreed ... that courts should decide constitutional cases on the basis of "fixed principles ... stamped with the seals of truth and authority."'334 Robert Clinton notes that public reaction to Marbury was "very mild" and that this "lack of public controversy derive[d] from the general acceptability of the decision itself and the opinion that justified it." 335 Larry Kramer agrees, explaining that by the time Marbury was issued in 1803 , its "main prin-

could be trumped, with a particular focus on Thomas Jefferson's concerns regarding the judiciary's lack of political accountability. See Friedman, supra note 5, at 375-8I. As evidenced by the Kentucky debates, see supra section II.B, pp. 869-77, the distinction between constitutional law and ordinary law was maintained by many judicial review opponents into the 1820 .

326 Clinton, supra note 10, at 99.

327 Id. at 18 (emphasis omitted).

328 NELSON, supra note I0, at 77 (quoting Grimball v. Ross, T.U.P. Charlt. I75, 177 (Ga. Super. Ct. 1808$)$ ).

329 Id. (quoting United States v. The William, 28 F. Cas. 614, 620 (D. Mass. 1808) (No. 16,700)) (internal quotation marks omitted).

330 See id. at $63-64$.

331 One exception to this trend may be Thomas Grey, whose work suggests that judges in the early United States were more willing and able to review statutes based on unwritten constitutional norms than are judges in the modern age of constitutional positivism. See Thomas C. Grey, The Original Understanding and the Unwritten Constitution, in TOWARD A MORE PERFECT UNION: SIX ESSAYS ON THE CONSTITUTION 145, I68 (Neil L. York ed., 1988).

332 NELSON, supra note Io, at 63 .

333 Id. at 75 .

334 Id. at 77 (second omission in original) (quoting Grimball v. Ross, T.U.P. Charlt. I75, I 77 (Ga. Super. Ct. I808)).

335 Clinton, supra note 10, at I02-03 
[Vol. I $17: 826$

ciples were already widely accepted" and "most people thought the power [of judicial review] existed." ${ }_{336}$ Even where disagreement existed, it was arrayed along a relatively narrow spectrum, with Jeffersonian departmentalism the most critical of judicial authority though even this view conceded at least a narrow coordinate power of judicial review in particular cases and controversies. ${ }^{337}$ As scholarly reexaminations of Marshall's position in Marbury successively cast it as more modest and accommodating of coordinate constitutional interpretation, this spectrum of disagreement narrows further to something approaching consensus.

2. An Uncertain Consensus. - The Kentucky episode complicates this story by revealing that the range of disagreement in public attitudes over judicial review was significantly broader than that displayed in national political debates. The Kentucky critics of judicial review did not articulate their opposition in departmentalist terms, but rather argued for a complete ouster of the judges from any constitutional review. "[W]e appoint judges... but it is never understood that they will judge our laws," said one important newcourt pamphlet. ${ }^{338}$ In successive elections, a large portion of the voting public endorsed this outright rejection of judicial review, demonstrating that many Kentuckians shared this conception of exclusive constitutional authority vested in the public or their agents in the legislature. That such deep popular disagreement about judicial power existed so late into the American experiment reveals how much remained unresolved even two decades after Marbury. At least for the Kentucky electorate, neither Marbury nor any antecedent constitutional understanding established anything close to a universal consensus in favor of judicial review.

That all of this opposition to judicial review was roiling beneath the surface of an apparent consensus to the contrary among national political figures illustrates that a focus on national politics might overstate public acceptance of the doctrine at that time. As described earlier, there are a number of reasons why opposition to the judiciary's basic horizontal review power did not surface in the realm of national politics in the early 1800 ; these include the much more contentious debates over the vertical allocation of federal and state power, the partisan fractures of the time, and the Marshall Court's exceedingly restrained behavior relative to coordinate legislative acts. ${ }^{339}$ Most importantly, however, national political discourse was a dialogue among economic and professional elites who tended to agree on the judicial

\footnotetext{
336 Kramer, supra note 5 , at $87-88$.

337 See supra pp. $883-84$ for a discussion of Jefferson's departmentalist philosophy.

338 LIBERTY SAVED, supra note 6 , at 17.

339 See supra pp. $83 \mathrm{I}-33$.
} 
review question no matter how much they disagreed on other contested issues. William Nelson makes this point succinctly, stating that "the principles underlying Marbury... were unproblematic because political elites, the only people who discussed such issues, accepted the justices' views." 340 Barry Friedman makes a similar point, noting that the recorded material on judicial review in this period is inevitably "skewed toward elites," but he couples it with the suggestion that "[b]y delving into a wider set of sources... it is possible to obtain a reflection of what a broad base of society was thinking." 341

The Kentucky debate generated just such a "wider set of sources," and prolifically so. These sources explain much about the apparent inconsistency between the national political consensus on horizontal judicial review and this local disagreement. Kentucky's broad suffrage rules and relatively literate electorate facilitated (and compelled) appeal to a broader range of public opinion than did the filtered realm of national politics, and the result was the written expression of a much greater range of debate about the basic legitimacy of judicial review. At the very least, the Kentucky crisis differed from national politics in this sense, revealing that the secure consensus among national leaders regarding judicial review had not yet taken hold at this particular place and time. The question then becomes whether non-elite skepticism toward judicial review extended beyond the geographic limits of Kentucky. If the wider American public was less enamored of judicial review than were the players in national politics, we might expect to have seen other severe state-level outbreaks of opposition to judicial review. But episodes as extreme as Kentucky's did not occur elsewhere. The Kentucky crisis was an anomaly.

But this does not yet resolve the question of whether its citizens' attitudes were likewise anomalous. In considering this question, Friedman's general framework ${ }^{342}$ is again useful, for it acknowledges that significant public skepticism about judicial review can exist without triggering overt episodes of sustained opposition. The development of a robust popular objection to judicial review typically requires not just a background attitudinal distrust of judicial authority, but also a confluence of several more specific factual predicates. As explored in detail in Part I above, the Kentucky episode was triggered by four distinctive factual conditions: the double-barreled exercise of unpopular judicial review by the federal and state supreme courts almost simultaneously, the judicial interference with remedial positivism in the state's most important area of public policy (land regulation), the

\footnotetext{
340 NELSON, supra note IO, at 70.

341 Friedman, supra note 5, at 355-56.

342 See supra p. 832
} 
state's history of popular constitutionalism, and the retention of an unaccountable life-tenured judiciary when some otherwise similarly majoritarian states (like Ohio) had implemented fixed appointment terms for judges. The fact that more overt debate on judicial review did not occur contemporaneously in other states probably had as much to do with the absence of these specific triggers - and, relatedly, with the generally restrained behavior by most state judiciaries of the era as with any Kentucky exceptionalism in terms of background public aititudes.

Indeed, many of the underlying public attitudes that surfaced in and fueled the Kentucky debates were not unique to that state. Several other states shared Kentucky's majoritarian political emphasis, with its focus on robust electioneering and campaign literature, and the Kentucky electorate's antipathy toward elite institutions like the Bank of the United States. In addition, many throughout the United States shared the distrust of lawyers and legal reasoning that motivated much of the Kentucky opposition to judicial constitutionalism. ${ }^{343}$ Within a decade or two of the Kentucky crisis, many states amended their constitutions to provide for elected judiciaries, suggesting that opposition to judicial review by unaccountable judges may have existed elsewhere in the 1820 s. It may be that Kentuckians' attitudes were more closely aligned with those of citizens in other states in the New West and less so with those of citizens in the older eastern states - but to say that an idiom of political thought was "western" at that time is hardly to marginalize it, given the subsequent Jacksonian ascendancy. In sum, though we know that the Kentucky crisis was unique, we can infer that its citizens' underlying doubts about judicial review were not. The fact that opposition to the basic judicial review power may have persisted among at least a large minority of the American public two decades after Marbury urges caution against too broadly ascribing the emerging national political consensus on judicial review to the public at large.

3. The Public's Constitutional Moment. - Once this fractious discord about judicial review surfaced in Kentucky in 1823 , the dynamic in which the populace worked out its disagreement is revealing. This was a debate about judicial review that was resolved by popular electoral politics without recourse to the normal interactive function usually served by the courts. The early success of the new-court opponents temporarily removed courts from the dialogue and created a uniquely monistic political space in which the public debated whether it preferred to perpetuate that state of affairs. All of the standard higher lawmaking criteria were in place: depth, breadth, and focus in

343 See, e.g., ELLIS, supra note 73, passim. 
the public discourse, along with apparent acknowledgment by both sides that the public's choice on the question would settle things. ${ }^{344}$ Despite initial dire predictions of imminent armed conflict, the only violence that occurred took the form of overheated rhetorical flourish, and the Kentucky public not only ultimately resolved its constitutional discord within the political framework, but even reversed its substantive course. This is, then, an example of popular higher lawmaking working as its theoretical proponents say it should, with the people stepping forward to deliberate, and ultimately decide, key constitutional questions.

The choice that Kentuckians made was an endorsement of a world with judicial review, or at least a rejection of a world without it. Despite the public disagreement mentioned above and Kentucky's ultramajoritarian leanings, a healthy majority of the voters ultimately came to support a reinstatement of judicial review. Shifting the focus away from the bitterly divisive rhetoric of early 1824 and 1825 and looking instead at the electoral results of 1825 and 1826 , we can discern an electoral mandate for the old-court party's bid to reestablish judicial review. Viewed in this light, the Kentucky episode offers some confirmation of the claim that Americans were generally coming to accept a limited form of judicial review. Although it cannot be said that all (or even almost all) of the Kentucky public accepted judicial review, a significant majority did so, and in successive elections. Ultimately, how we interpret this lopsided disagreement depends on the meaning we give to common scholarly terms like "consensus," "understanding," and "acceptance." Does support from sixty percent of the electorate constitute a shared understanding? Does a dissenting minority of almost forty percent preclude claims of consensus? If the answers to such questions are ambiguous, so too perhaps is the meaning of the Kentucky crisis and its resolution.

Moreover, as with any election posing a binary choice, there exists additional uncertainty over whether the Kentucky voters were embracing judicial review so much as they were rejecting the alternative before them at the time - the new-court vision of legislative sovereignty. The new-court party's early success may have worked against it in a political sense. By succeeding at the outset of the crisis and doing away with the countervailing authority of the old court, the judicial review opponents lost the critic's privilege of always taking the argumentative offensive, and instead had to defend their own regime against the old-court theoretical assaults. These assaults took two primary, mildly inconsistent forms: first, that the new-court regime

344 For Bruce Ackerman's framework of higher lawmaking, see I ACKERMAN, supra note I3, at $266-80$. 
[Vol. I I $7: 826$

gave too much effect to majority will, thereby jeopardizing minority rights; and second, that the regime did not adequately reflect the people's will because the legislature was itself unfaithful to the public and thus needed judicial control. The public reinstatement of judicial review was almost certainly motivated as much by these concerns about the alternative choice as by an enthusiastic embrace of judicial authority.

4. Taming the Judges. - What emerges from all of this is a picture of an electorate that retained profound distrust of judicial authority, but was unwilling to dispense with it altogether and leave the legislature (or even itself) uncontrolled by the courts. How did the public reconcile this conceptual tension? In the short run, the answer is clear: it chose to reestablish judicial review, but in a form much more modest than that articulated by the modern doctrine. Even as described by old-court supporters, the judicial review that was at issue in the elections was limited in several respects. ${ }^{345}$ First, the legislature retained authority as a coordinate interpreter of the constitution within its sphere of action; second, courts would confine their constitutional review to specific instances of private litigation involving private rights; third, courts continued to profess adherence to a form of the doubtfulcase rule, under which they would find statutes unconstitutional only if the inconsistency was "obvious and palpable"; and finally, and most importantly, the old court's model of judicial review acknowledged the public's critical and continuing role in the interpretive project, conceding that there may be "constitutional questions which can be decided only by the people; and their only mode of deciding them is at the polls." 346

Thus confined, judicial review offered a compromise solution and provided common ground upon which a majority of the Kentucky electorate could agree. It is in this sense that the Kentucky episode correlates most neatly with accounts of recent scholars who have made similar points about the narrower scope of early-nineteenth-century judicial review on a more national scale. Whatever can be claimed about the general acceptance of judicial review in this era, it was an acceptance generated in significant part by the modest character of the doctrine at issue. Of course, this early-nineteenth-century compromise did not hold, and the nation and the states went in different directions in the following decades. There is little doubt about the direction that the national story took, and scholars like Larry Kramer and Barry Friedman give comprehensive accounts of a gradual accretion of judicial authority through the nineteenth and twentieth centuries, culmi-

\footnotetext{
345 See supra section II.B.2, pp. 874-77, for more discussion of these limiting principles

346 PLEBIAN, supra note I2, at I 24.
} 
nating in a more assertive judicial supremacy, if not judicial sovereignty or exclusivity. ${ }^{347}$

The majority of the states went in the opposite direction, though, resolving unease over unaccountable judicial authority by subjecting state judiciaries to electoral control in the mid-nineteenth century. ${ }^{348}$ For Americans who distrusted judicial power but were likewise skeptical of the fidelity and wisdom of their legislative agents, an elected judiciary offered a more palatable alternative than the new-court model of legislative supremacy debated earlier in Kentucky. By retaining judicial review, the people kept in place a coordinate structural check on unfaithful legislators; by taming judicial discretion with electoral accountability, they rectified some of the pernicious aspects of judicial review that had so enraged the Kentucky electorate. This observation helps illuminate the failure of the Kentucky new-court advocates' critique of judicial review. They identified the right problem, as far as many Americans were concerned at the time, but offered the wrong solution - one too extreme to appeal to a majority of the public.

347 See Friedman, supra note 5 ; Kramer, supra note 5

348 Of the sixteen already-existing states that held constitutional conventions between $184^{5}$ and I 860, fourteen, including Kentucky, provided for popular election of judges. Furthermore, every state that entered the union between 1846 and 1912 instituted an elected judiciary. For a summary of these developments and the literature assessing them, see Caleb Nelson, $A$ Re-Evaluation of Scholarly Explanations for the Rise of the Elective Judiciary in Antebellum America, 37 AM. J. LEGAL HIST. 190 (1993). See also Kermit L. Hall, The Judiciary on Thial: State Constitutional Reform and the Rise of an Elected Judiciary, 1846-1860, 45 HISTORIAN 337 (1983). 